\title{
Comparison of analytical and predictive methods for water, protein, fat, sugar, and gross energy in marine mammal milk
}

\author{
O. T. Oftedal, ${ }^{* 1}$ R. Eisert, ${ }^{*} \dagger$ and G. K. Barrell \\ ${ }^{*}$ Smithsonian Environmental Research Center, Smithsonian Institution, Edgewater, MD 21037 \\ †Gateway Antarctica, University of Canterbury, Christchurch 8140, New Zealand \\ $\ddagger$ Faculty of Agriculture and Life Sciences, PO Box 84, Lincoln University, Lincoln 7647, New Zealand
}

\section{ABSTRACT}

Mammalian milks may differ greatly in composition from cow milk, and these differences may affect the performance of analytical methods. High-fat, high-protein milks with a preponderance of oligosaccharides, such as those produced by many marine mammals, present a particular challenge. We compared the performance of several methods against reference procedures using Weddell seal (Leptonychotes weddellii) milk of highly varied composition (by reference methods: $27-63 \%$ water, $24-62 \%$ fat, $8-12 \%$ crude protein, $0.5-1.8 \%$ sugar). A microdrying step preparatory to carbon-hydrogennitrogen $(\mathrm{CHN})$ gas analysis slightly underestimated water content and had a higher repeatability relative standard deviation $\left(\mathrm{RSD}_{\mathrm{r}}\right)$ than did reference oven drying at $100^{\circ} \mathrm{C}$. Compared with a reference macroKjeldahl protein procedure, the CHN (or Dumas) combustion method had a somewhat higher $\mathrm{RSD}_{\mathrm{r}}(1.56$ vs. $0.60 \%$ ) but correlation between methods was high (0.992), means were not different (CHN: $17.2 \pm 0.46 \%$ dry matter basis; Kjeldahl $17.3 \pm 0.49 \%$ dry matter basis), there were no significant proportional or constant errors, and predictive performance was high. A carbon stoichiometric procedure based on CHN analysis failed to adequately predict fat (reference: Röse-Gottlieb method) or total sugar (reference: phenol-sulfuric acid method). Gross energy content, calculated from energetic factors and results from reference methods for fat, protein, and total sugar, accurately predicted gross energy as measured by bomb calorimetry. We conclude that the CHN (Dumas) combustion method and calculation of gross energy are acceptable analytical approaches for marine mammal milk, but fat and sugar require separate analysis by appropriate analytic methods and cannot be adequately estimated by carbon stoichiometry. Some other alternative methods-lowtemperature drying for water determination; Bradford,

Received January 2, 2014.

Accepted April 19, 2014.

${ }^{1}$ Corresponding author: oftedalo@si.edu
Lowry, and biuret methods for protein; the Folch and the Bligh and Dyer methods for fat; and enzymatic and reducing sugar methods for total sugar - appear likely to produce substantial error in marine mammal milks. It is important that alternative analytical methods be properly validated against a reference method before being used, especially for mammalian milks that differ greatly from cow milk in analyte characteristics and concentrations.

Key words: marine mammal milk, method validation, Dumas method, carbon stoichiometry

\section{INTRODUCTION}

Analytical methods for dairy products are subject to strict quality control, including interlaboratory collaborative studies that assess assay performance and the validity of alternative methods (Barbano et al., 1988, 1990; Lynch and Barbano, 1999; Hooi et al., 2004; Barbano and Lynch, 2006). Unfortunately, the same is not true for analysis of the wide variety of milks produced by other mammals, where diverse analytical methods have been used without standardization or method validation (Oftedal and Iverson, 1995). Methods that are well validated for cow milk may or may not be suitable for other milks, depending in part on the sensitivity of assays to structural differences in particular milk constituents. Many protein and sugar methods may give different responses as a consequence of differences in the structure and amino acid composition of proteins and in the proportion and composition of oligosaccharides, respectively, whereas some assays are subject to interference from other milk constituents (Keller and Neville, 1986; Atwood and Hartmann, 1992; Oftedal and Iverson, 1995; Kamizake et al., 2003; Tremblay et al., 2003; Eisert et al., 2013). Commonly used fat extraction procedures may fail to fully recover the high lipid content of some mammalian milks (Iverson and Oftedal, 1995; Iverson et al., 2010).

Analytic inaccuracy is of particular concern for milks that are very different in composition from the milks of dairy animals, especially marine mammals. The 
milks of marine mammals are not only much higher in fat (typically $15-40 \%$ in cetaceans and $25-60 \%$ in pinnipeds) than cow milk (2-5\%, depending on breed; e.g., Myburgh et al. 2012), but contain much greater diversity and abundance of long-chain PUFA and, in some taxa, more complex oligosaccharides than do the milks of dairy animals (Iverson and Oftedal, 1995; Urashima et al., 2011; Oftedal, 2011). In some taxa, NPN may represent a large portion of total N, FFA may be present if samples are handled inappropriately, and instability of thawed milks may lead to substantial sample-to-sample heterogeneity (Oftedal et al., 1987; Ochoa-Acuna et al., 1999). Information on the content of specific milk proteins is limited, but at least some marine mammals secrete $\alpha_{\mathrm{S}^{-}}, \alpha_{\mathrm{S}^{-}}, \beta-$, and $\kappa-\mathrm{CN}$, $\beta$-LG, $\alpha$-LA, serum albumin, and the milk fat globule proteins butyrophilin 1 and xanthine oxidase (Oftedal, 2011). Fur seals and sea lions (family Otariidae) and walrus (family Odobenidae) have lost the ability to synthesize functional $\alpha$-LA and thus produce milks devoid of lactose and lactose-based oligosaccharides (Reich and Arnould, 2007; Sharp et al., 2008; Urashima et al., 2001; Oftedal, 2011).

The earliest analyses of marine mammal milks date back to the 19th century (harbor porpoise, Phocoena phocoena: Cooper, 1840; Purdie, 1885; long-finned pilot whale, Globicephala melas: Frankland and Hambly, 1890), but the analytical methods that have since been used have varied greatly. For example, in the past $50 \mathrm{yr}$, at least 8 different protein methods (biuret, Bradford, Dumas, Fourier transform infrared spectroscopy, Lowry, macro-Kjeldahl, micro-Kjeldahl, nesslerization) have been used for milks of cetaceans, sirenians (manatees), pinnipeds, and other marine carnivores (polar bear, sea otter) but the extent to which these give comparable results is not clear (see Discussion).

The time, expertise, and large sample volume required for many established methods of milk analysis underlie the practical interest in alternative methods, especially micro-methods for small milk samples from rodents and other small mammals (Hood et al., 2009) or from animals at remote locations that are difficult to sample, such as marine mammals (Arnould et al., 1995). One attractive method due to small sample-size requirements is carbon-hydrogen-nitrogen $(\mathbf{C H N})$ gas analysis, an instrumental modification of the Dumas method of nitrogen analysis (e.g., ISO-IDF, 2002). This method has generated comparable results to the macro-Kjeldahl method for organic $\mathrm{N}$ in many, but not all, method comparisons involving dairy products ( $\mathrm{Si}-$ monne et al., 1997; Wiles et al., 1998; ISO-IDF, 2002; Tremblay et al., 2003). For cow milk (fresh, dry, skim, or low fat), CHN/Dumas N averages between 97 and $103 \%$ of Kjeldahl N (Simonne et al., 1997; Etheridge et al., 1998; Wiles et al., 1998; ISO-IDF, 2002; Thompson et al., 2002), discrepancies that have foiled efforts to designate the Dumas method as an approved method for fluid cow milk (Lynch and Barbano, 1999; ISO-IDF, 2002).

Our goal was to evaluate performance of the CHN gas analysis method and accompanying procedures when applied to marine mammal milk of very different composition from dairy products. Arnould et al. (1995) were the first to propose use of the CHN or Dumas method for determination of the protein content of marine mammal milk, and they concluded that stoichiometric accounting of the distribution of the carbon so measured also allowed the prediction of milk fat (but not sugar) content. The CHN plus stoichiometry approach was subsequently used to characterize milk composition of the Antarctic fur seal (Arctocephalus gazella) and Australian fur seal (Arctocephalus pusillus doriferus; Arnould and Boyd, 1995; Arnould and Hindell, 1999); the CHN method (without carbon stoichiometry) has also been used to measure milk CP content of bottlenose dolphins (Tursiops truncatus; West et al., 2007). However, no direct comparisons of CHN to other protein procedures have been made for the assay of marine mammal milks. Hood et al. (2009) suggested that lack of homogeneity in high-fat or improperly stored milks might produce unacceptably high replicate coefficients of variation (or repeatability relative standard deviation, RSD ; Wehr, 2004), given the small subsample volumes often used in CHN analysis. Larger amounts, especially of high-fat milks, can overload the combustion chamber, producing incomplete combustion and erroneous results (O. T. Oftedal, unpublished data). Thus, special care is necessary in sampling marine mammal milks that may be as much as $60 \%$ fat on a wet weight basis.

The specific objectives of this study were to (1) examine the accuracy and precision of drying very small samples of milk in narrow, fluted tin vials, as used in CHN analysis; (2) compare total $\mathrm{N}$ content as assayed by $\mathrm{CHN}$ analysis to results obtained by a macro-Kjeldahl procedure adapted to high-fat samples; (3) determine whether carbon stoichiometry based on CHN analysis produces a sufficiently accurate and precise estimate of milk fat and total sugar content compared with the Röse-Gottlieb and phenol-sulfuric acid methods, respectively; and (4) determine whether published energetic conversion factors for protein, fat, and sugar accurately predict milk gross energy (GE) content, as determined by adiabatic bomb calorimetry.

As test material for methods comparisons, we used milk of the Weddell seal Leptonychotes weddellii (Carnivora: Pinnipedia; Family Phocidae). The Weddell seal is an Antarctic species that breeds further south 
than any other mammal, utilizing annual or multiyear frozen ice platforms attached to land ("fast ice"); pups are nursed for about 6 wk on milk that is high in fat, reaching plateau levels of about $54 \%$ fat by $2.5 \mathrm{wk}$ postpartum (Eisert et al., 2013). The results reported herein for macro-drying, Röse-Gottlieb, macro-Kjeldahl, and phenol-sulfuric acid assays (considered reference methods for the present purposes) are a subset of recently published milk composition data (Eisert et al., 2013), and thus will only be discussed in the context of assessing alternative methods.

\section{MATERIALS AND METHODS}

\section{Milk Collection and Animal Procedures}

Milk was obtained from Weddell seals rearing pups on fast ice near Hutton Cliffs, McMurdo Sound, Ross Sea, Antarctica $\left(77^{\circ} 44^{\prime} \mathrm{S}, 166^{\circ} 30^{\prime} \mathrm{E}\right)$. Details of sampling procedures are provided in Eisert et al. (2013); samples were frozen on dry ice or at $-80^{\circ} \mathrm{C}$ in the field, and kept at $-80^{\circ} \mathrm{C}$ during storage. Samples were collected and transported under authority of the following permits and approvals: New Zealand Department of Conservation permit (dated 28 September 1998); Environmental Authorisation no. 98/11 issued by Antarctica New Zealand to G. K. Barrell; Marine Mammal Protection Act Permits 763-1534-01 and 763-1485-01 issued by the US National Marine Fisheries Service; Antarctic Conservation Act permit 2007-01 issued by the National Science Foundation Office of Polar Programs; ethics approvals by Lincoln University Animal Ethics Committee and the Animal Care and Use Committee of the Conservation and Research Center of the Smithsonian National Zoological Park.

\section{Milk Analysis}

For analysis, vials of frozen milk sample were immersed in warm water $\left(40-50^{\circ} \mathrm{C}\right)$ to promote rapid thawing and minimize phase separation; samples were thoroughly mixed by multiple gentle inversions before removal of each aliquot.

Water. Dry matter (DM or TS) content of milk was determined using 2 different procedures. For the reference drying method (Sherbon et al., 1978; Hooi et al., 2004), subsamples [each $\sim 1 \mathrm{~g}$ of whole milk (WM), equivalent to $\sim 0.6 \mathrm{~g}$ of $\mathrm{DM} ; \mathrm{n}=3$ replicates per sample] were placed in aluminum pans $(\sim 4.5 \mathrm{~cm}$ in diameter) and dried at $100^{\circ} \mathrm{C}$ for $4 \mathrm{~h}$ in a forced convection oven, cooled in a desiccator, and weighed promptly upon removal from the desiccator.

In the alternative microdrying method, flat-bottomed, fluted tin CHN capsules, open at the top, were predried at $100^{\circ} \mathrm{C}$ in a forced convection oven and weighed to $0.01 \mathrm{mg}$ on a microbalance (mean $\pm \mathrm{SD}$ : $31.71 \pm 0.39 \mathrm{mg})$. Subsamples $(\sim 2.5-4 \mathrm{mg}$ of WM; $\mathrm{n}$ $=7-10$ replicates per sample) were pipetted into the capsules. Capsules were set in an aluminum block with wells to prevent tipping and provide uniformity in heating, and dried for $2.5 \mathrm{~h}$ at $100^{\circ} \mathrm{C}$ in a forced convection oven. Samples were cooled to room temperature in a desiccator and rapidly weighed. Wet and dried subsamples represented about 7 to $14 \%$ and 4 to $10 \%$ of empty capsule weight, respectively. This procedure is a preparative step for CHN gas analysis (see below). Blanks without milk that were incorporated in each CHN run were handled similarly. Water content of milk was calculated as water $\%=100-\mathrm{DM} \%$.

$\boldsymbol{C P}$. For the reference macro-Kjeldahl method (Bradstreet, 1965; Lynch and Barbano, 1999), milk samples $(\sim 1 \mathrm{~g}$ in triplicate) were digested and distilled in a hooded combination Kjeldahl unit (Labconco, Kansas City, MO); performance of individual heating units was regularly checked and adjusted by boil tests to ensure equal heating at all positions (Lynch and Barbano, 1999). Thawed, mixed subsamples were digested in 30 $\mathrm{mL}$ of concentrated $\mathrm{H}_{2} \mathrm{SO}_{4}$ (see Discussion for rationale) to which boiling chips, 2 FisherTab CT-50 Kjeldahl tablets [containing $0.3 \mathrm{~g}$ of copper (II) sulfate catalyst and $10 \mathrm{~g}$ of potassium sulfate; Fisher Scientific, Fair Lawn, NJ] were added. Boiling was continued for $1 \mathrm{~h}$ after clearing. The digests were cooled, diluted with distilled water, rendered basic with concentrated $\mathrm{NaOH}$, and distilled into a saturated boric acid $\left(\mathrm{H}_{3} \mathrm{BO}_{3}\right)$ solution containing a $\mathrm{pH}$ indicator (Kjel-Sorb solution, SK1520, Fisher Scientific). Ammonium $\left(\mathrm{NH}_{4}{ }^{+}\right)$in distillates was titrated with $0.100 \mathrm{M} \mathrm{HCl}$. Nitrogen recovery in this system, based on controlled trials using sucrose (to account for organic matter) and ammonium sulfate $\left[\left(\mathrm{NH}_{4}\right)_{2} \mathrm{SO}_{4}\right]$, is about $99 \%$. Recovery of total $\mathrm{N}(\mathbf{T N})$ from seal milk was also checked by analyzing a pooled sample of seal milk ( $\mathrm{n}=6$ replicates per treatment) with or without added ammonium sulfate.

For the alternative Dumas (CHN) combustion method, 2.5 - to 4 -mg replicates ( $\mathrm{n}=7$ per sample) were dried in tin CHN capsules (see above, for microdrying method) after careful folding. The capsules were combusted in a CHN elemental gas analyzer (model 2400, series 2, Perkin Elmer Co., Norwalk, CT) at a combustion temperature of $950^{\circ} \mathrm{C}$ with supplemental oxygen boosts of 2 s. The combustion tube contained chromic oxide, silver tungstate on magnesium oxide, silver vanadate, and silver gauze, and the reduction tube contained copper plus, copper oxide, copper rod, and silver gauze, as recommended by the instrument manufacturer. Analyzer response was calibrated via repeated blank, K-factor, and acetanilide ( $N$-phenylacetamide) runs. 
Crude protein was estimated as $\mathrm{TN} \times 6.38$. To allow comparison of methods, Kjeldahl-CP results were converted to a DM basis using DM as determined by the reference drying method (see Eisert et al., 2013 for unconverted Kjeldahl results). The accuracy of TN determination by both methods was checked by analyzing a National Institute of Standards and Technology (NIST) Standard Reference Material (SRM 8435, Whole Milk Powder).

Fat. For the reference Röse-Gottlieb method (Case et al., 1985; AOAC International, 1995), triplicate subsamples (containing $\sim 0.25 \mathrm{~g}$ fat, i.e., about 0.5 to $0.8 \mathrm{~g}$ of milk, depending on lactation stage) were diluted with distilled water and sequentially extracted in Röhrig tubes by additions of ammonium hydroxide, ethanol, diethyl ether, and petroleum ether. The ether extraction series was repeated thrice, and the ether layer was collected into aluminum pans with care to rinse the spout and cap of the Röhrig tube. Ether was evaporated by placing pans on a covered steam bath in an explosion-proof hood, and the pans were dried briefly at $100^{\circ} \mathrm{C}$, cooled in a desiccator, and weighed. The fat was resolubilized and removed with boiling petroleum ether, taking care to rinse all surfaces repeatedly and to not dislodge any precipitate, if observed. Pans were oven-dried, cooled in a large desiccator, and reweighed. Fat was determined by difference. Blanks were not routinely performed but in previous studies were found to be so small as to be difficult to measure; care to achieve final thermal equilibrium of pans was, however, important.

For the first alternative method, we used the carbon stoichiometric method (Gnaiger and Bitterlich, 1984) as proposed for milk analysis by Arnould et al. (1995). Fat was calculated by a stoichiometric approach, using $\mathrm{C}$ and $\mathrm{N}$ results generated by $\mathrm{CHN}$ elemental analysis of Weddell seal milk samples (as described for CP, above). The stoichiometric approach uses fixed input factors representing the average elemental composition of lipid, true protein, and carbohydrate. The C, H, and $\mathrm{N}$ contents of Weddell seal milk fat were determined directly: lipid extracted by the Röse-Gottlieb procedure (see above, $\mathrm{n}=21$ ) was solidified by freezing, scooped with a small spatula into tin CHN vials, dried, weighed on a microbalance $(\sim 1.5 \mathrm{mg}, 3-6$ replicates per fat sample), and assayed by CHN elemental analysis (using the procedure described above; total assays, $\mathrm{n}$ $=119$ ). The $\mathrm{C}$ and $\mathrm{N}$ contents of Weddell seal milk protein were assumed to be equivalent to cow milk protein. We calculated C:N mass ratios for the caseins and whey proteins of cow milk, based on AA composition of individual proteins (Fox, 2003; supplemented by AA sequence data at UniProt, www.uniprot.org). The C:N ratios of caseins and whey proteins averaged
3.39 and 3.20; we used an average C:N ratio of 3.30. To correct TN (as determined by CHN analysis) to protein $\mathrm{N}$, we measured NPN in 15 Weddell seal milk samples by Kjeldahl analysis after precipitation of protein with trichloroacetic acid; the average value (expressed as a fraction of $\mathrm{TN}$ ) was applied to all samples. The $\mathrm{C}$ content of sugar (43.8\%) was calculated from molecular formulas assuming that Weddell seal milk sugar contains an approximate 1:2:2 ratio of lactose, 2'-fucosyllactose and lacto- $N$-neotetraose [Oftedal, 2011; T. Urashima (Obihiro University of Agriculture and

Veterinary Medicine, Obihiro, Japan), O. T. Oftedal, and R. Eisert, unpublished data]. The equations of Gnaiger and Bitterlich (1984) include a correction factor for residual water. We estimated that our microdried samples contained, on average, $0.74 \%$ residual water (see Discussion). Because predictions obtained by the equations of Gnaiger and Bitterlich (1984) are expressed as the fraction of organic dry matter (OM; DM minus ash), we measured ash content of all milk samples by incineration of triplicate macro-dried milk samples in a muffle furnace. Oven temperature was increased gradually to $550^{\circ} \mathrm{C}$ and held at that temperature for 5 h (Eisert et al., 2013). We recalculated our results on an OM basis to allow direct comparison of predicted results to analytical results.

For the second alternative method, and to evaluate a simpler alternative to the stoichiometric method, we also predicted fat by a microgravimetric method using as inputs only the percentage DM from microdrying and percentage $\mathrm{TN}$ from CHN elemental analysis. In this method,

$$
\begin{gathered}
\text { Predicted fat }(\% \text { in milk })=100 \% \\
-(\text { water }+ \text { protein }+ \text { ash }+ \text { sugar }) \%, \\
\text { Predicted fat }(\% \text { in milk })=\mathrm{DM} \% \\
-(\mathrm{TN} \% \times 6.38+2.13),
\end{gathered}
$$

where $2.13 \%$ is a constant based on the average sum of sugar and ash in Weddell seal milk $(1.68 \%, \mathrm{n}=47)$ plus the average overestimation of DM by microdrying $(0.45 \%$ of $\mathrm{WM}$, equivalent to $\sim 0.74 \%$ in $\mathrm{DM}$; see Results).

Sugar. For the reference phenol-sulfuric acid method (modified from Marier and Boulet, 1959), triplicate subsamples of milk were diluted with distilled water to contain 10 to $50 \mu \mathrm{g} / \mathrm{mL}$ sugar, and each diluted subsample was assayed in triplicate (3 tubes). Into each tube, $1 \mathrm{~mL}$ of $11 \%$ phenol solution, $1.6 \mathrm{~mL}$ of subsample (or standard), and $7.4 \mathrm{~mL}$ of concentrated $\mathrm{H}_{2} \mathrm{SO}_{4}$ were added, with vortexing after each addition. Tubes were 
left to react for precisely $10 \mathrm{~min}$, and then placed in a water bath at room temperature. Tubes were swirled to eliminate stratification and any bubbles were allowed to rise to the surface before reading. Subsamples were read at $490 \mathrm{~nm}$ using an automated sipper attached to a UV-visible spectrophotometer (Beckman DU model 640, Beckman Coulter, Fullerton, CA). The time from placement of a tube in the water bath until reading did not exceed $1 \mathrm{~h}$. Standard curves (10 to $50 \mu \mathrm{g} / \mathrm{mL}$ ) were prepared using lactose monohydrate; results so expressed represent the monosaccharide equivalent of an equimolar mixture of glucose and galactose.

For the alternative stoichiometric method, milk sugar (carbohydrate) content was estimated by stoichiometry, according to Gnaiger and Bitterlich (1984), but with the modified species-specific inputs for the elemental composition of fat, protein, and sugar, and for residual water in measured DM, as described above.

$\boldsymbol{G E}$. For the reference bomb calorimetric method, the GE content of a subset of milk samples $(\mathrm{n}=20)$ was measured in triplicate in an adiabatic bomb calorimeter (model 1241, Parr Instrument Company, Moline, IL) after milk samples had been dried onto a cotton base. Cotton wool buds were ether-washed and dried, and their GE content was measured $(4,109 \pm 25 \mathrm{cal} / \mathrm{g}$, $\mathrm{n}=15)$. Weighed amounts of milk $(\sim 0.20-0.25 \mathrm{~g}$ of $\mathrm{WM}$ ) were added to weighed amounts of the cotton in calorimeter cups and dried overnight at $60^{\circ} \mathrm{C}$ (to avoid generation of Maillard products), cooled in a desiccator, and weighed. After sample combustion, residual fuse wire and residual acid were measured, with corrections applied to calorimetry data. The energy content of the cotton was subtracted from the total energy measurement to obtain milk GE content. Bomb results in calories per gram were converted to kilojoules per gram $(\times 0.004184)$.

In the alternative method, GE content was calculated using factors of $38.1,24.5$, and $16.5 \mathrm{~kJ} / \mathrm{g}$ for the energy content of milk fat, CP, and sugar (Perrin, 1958; Oftedal, 1984) using results from reference methods (macro-Kjeldahl, Röse-Gottlieb, and phenolsulfuric acid methods, respectively). The GE content of a pooled sample of Weddell seal milk fat (obtained via the Röse-Gottlieb method) was analyzed by bomb calorimetry (as above) to determine energy content.

\section{Data Analysis and Comparison of Procedures}

Repeatability. Repeatability relative standard deviation $\left(\mathrm{RSD}_{\mathrm{r}}\right)$ was determined for the replicates of each sample, as follows:

$$
\mathrm{RSD}_{\mathrm{r}}=\frac{S_{r}}{\bar{x}} \times 100,
$$

where $\bar{x}$ is the mean and $S_{r}$ is the standard deviation of analytical replicates for that sample (Wehr, 2004) and is equivalent to the coefficient of variation of the replicates. We report the mean $\mathrm{RSD}_{\mathrm{r}} \pm$ its standard error (SE) across all samples for each assay.

Evaluation of Alternative Methods of Analysis. The performance of micromethods (microdrying and CHN CP) and of predictive models (stoichiometric and microgravimetric fat methods, calculated GE) was compared with results of reference methods run independently on the same sample. The equivalence of analytical procedures was assessed by correlation of results (Pearson's product-moment correlation) followed by regression analysis and paired comparison tests: (1) regression analysis was carried out by weighted Deming linear regression with specified analytical error ratio (Linnet, 1998) if Pearson $r \geq 0.995$, or by PassingBablok rank regression (Passing and Bablok, 1983; CBStat software, version 4.2.1, developed by Kristian Linnet, Vibevej 3, Risskov, Denmark) if Pearson $\mathrm{r}<$ 0.995 ; (2) paired data were compared by paired $t$-test (if normally distributed) or Wilcoxon signed-rank test (if not normally distributed). Three additional metrics were used to assess the agreement of results generated by alternative methods/prediction with results obtained from reference methods for individual samples: (a) a measure of relative error, the median relative error (MRE, Equation [3]; Sheiner and Beal, 1981), (b) a measure of absolute error, the root of the mean squared prediction error (RMSE, Equation [4]; Sheiner and Beal, 1981), and (c) a measure of overall predictive performance (prediction sum of squares, PRESS $\mathrm{r}^{2}$, Equation [5]; Allen, 1974; Dielman, 2005):

$$
\begin{gathered}
\text { Relative error }=100 \cdot \frac{\left(y_{i}-x_{i}\right)}{x_{i}}, \\
\text { RMSE }=\sqrt{\left[\frac{1}{N} \sum_{i=1}^{N}\left(y_{i}-x_{i}\right)^{2}\right]}, \\
\text { PRESS r }^{2}=1-\frac{\sum_{i=1}^{N}\left(y_{i}-x_{i}\right)^{2}}{\sum_{i=1}^{N}\left(x_{i}-\bar{x}\right)^{2}},
\end{gathered}
$$

where $x$ is the result of the reference method and $y$ is the result of the alternative or predictive method, and $N$ refers to the number of data pairs. The alternative or predictive method was considered suitable as a replacement for the reference method if all of the following criteria were fulfilled: (1) within-assay (repli- 
cate) repeatability was adequate; that is, $\mathrm{RSD}_{\mathrm{r}}<3 \%$ (Wehr, 2004)[ (2) Pearson correlation coefficient $r>$ 0.95 ; (3) the paired test was nonsignificant; (4) slope and intercept parameters from regression analysis did not differ from 1 and 0, respectively; and (5) acceptable predictive performance indicated by low relative and absolute errors and PRESS $r^{2}>0.95$. All analytical results were expressed as means \pm standard errors of the mean (SEM) on a whole milk (WM) basis unless otherwise specified.

\section{RESULTS}

The $\mathrm{RSD}_{\mathrm{r}}$ values for reference methods of analysis for $\mathrm{DM}$, fat, CP, sugar, ash, and GE were $0.62 \pm 0.07 \%$, $0.96 \pm 0.09 \%, 0.60 \pm 0.06 \%, 5.81 \pm 0.49 \%, 2.8 \pm 0.2 \%$, and $1.6 \% \pm 0.4 \%$, respectively. For samples in which all samples were assayed by reference methods (water, fat, $\mathrm{CP}$, sugar, and ash; $\mathrm{n}=58$ ), the sum of constituents was $99.8 \pm 0.18 \%$. For alternative methods, the $\mathrm{RSD}_{\mathrm{r}}$ values for DM (microdrying) and CP (Dumas/CHN) were $0.93 \pm 0.08 \%$ and $1.56 \pm 0.13 \%$.

Milk water as measured by microdrying is compared with the reference milk drying method in Figure 1A. Results were very highly correlated (Pearson $r=0.996$ ) and the slope was not different from 1 , but the intercept was negative and significantly different from 0 (Table 1). Overall, microdrying underestimated mean milk water content $(38.72 \pm 1.1 \% \mathrm{WM})$ by a small amount, on average $0.45 \% \mathrm{WM}$, relative to reference drying $(39.18$ $\pm 1.1 \% \mathrm{WM}$; paired $t$-test, $P=0.001)$. This difference, interpreted as residual water in microdried samples, accounted, on average, for $0.74 \%$ of apparent DM in microdried samples.

Crude protein determined by the Dumas (CHN) method is compared with macro-Kjeldahl results (expressed on a DM basis) in Figure 1B. The results of the 2 methods were tightly correlated (Pearson $\mathrm{r}=$ 0.992), the Passing-Bablok regression slope was not significantly different from 1 , and the intercept was not significantly different from 0 (Table 1 ). Overall, we detected no significant difference in results (by Wilcoxon signed rank test). Both methods measured the $\mathrm{N}$ content of standard whole milk reference material NIST 8435 accurately (NIST-declared nitrogen content 4.187 $\pm 0.043 \%$ in DM; Kjeldahl, $4.14 \pm 0.003 \%$, CHN, 4.16 $\pm 0.01 \%$ ). Recovery of added $\mathrm{N}$ (as ammonium sulfate) from seal milk was $100.1 \pm 0.5 \%$ using the Kjeldahl procedure.

Application of the carbon stoichiometric method required knowledge of the carbon content of the fat in Weddell seal milk and correction for NPN. The CHN analysis of samples of isolated milk fat $(\mathrm{n}=21)$ resulted in a mean elemental composition of $74.34 \pm 0.11 \% \mathrm{C}$,
$10.92 \pm 0.052 \% \mathrm{H}$, and traces of $\mathrm{N}(0.057 \pm 0.004 \%)$; NPN in Weddell seal milk averaged $0.061 \pm 0.0035 \%$ (n $=15$ ), equivalent to $4.23 \pm 0.34 \%$ of $\mathrm{TN}$.

The carbon stoichiometric prediction of fat content (Figure 2A) was positively correlated with fat measured by the Röse-Gottlieb method (Pearson $\mathrm{r}=$ $0.867, P<0.001$ ), and the slope and intercept were not significantly different from 1 and 0 , respectively (Table 1). However, the predicted fat $(83.1 \pm 0.83 \%$ $\mathrm{OM})$ was significantly greater (paired $t$-test $P<$ $0.001, \mathrm{n}=47)$ than measured fat $(80.3 \pm 0.78 \% \mathrm{OM})$. We observed considerable scatter for individual milk samples (Figure 2A), as evident in the poor predictive performance (PRESS $\left.r^{2}=0.417\right)$. Carbon stoichiometry failed to meet our criteria for an acceptable alternative method for estimating fat content of marine mammal milks.

The microgravimetric prediction of fat content (Figure 2B) was tightly correlated with measured fat (Pearson $r=0.991$ ), the Passing-Bablok regression slope was not significantly different from 1 , and the intercept was not significantly different from 0 (Table 1). Overall, we detected no significant difference in predicted and measured results ( 48.7 vs. $48.5 \% \mathrm{WM}$ basis; $P=0.15$, Wilcoxon signed rank test). Predictive performance was also much better for the microgravimetric prediction than the stoichiometric prediction, as indicated by the lower RMSE and higher PRESS ${ }^{2}$ (Table 1).

For milk sugar, the carbon stoichiometric method predicted an average sugar content of less than zero $(-0.30 \pm 0.44 \% \mathrm{OM})$ compared with a measured sugar content of $1.61 \pm 0.08 \%$ OM. Although we found a significant but weak correlation between predicted and measured sugar content (Pearson $\mathrm{r}=0.433, P=$ 0.002), more than half of the predicted sugar estimates ( $\mathrm{n}=26$ of 47$)$ were negative (not illustrated). Prediction of milk sugar content by the stoichiometric method was inadequate (MRE -153\%, RMSE 3.4, PRESS $\mathrm{r}^{2}$ $<0, \mathrm{n}=47)$ even when only nonnegative results were considered $[\mathrm{MRE}+16 \%$ ( -97 to $+481 \%)$, RMSE 2.0, PRESS $\left.\mathrm{r}^{2}<0, \mathrm{n}=21\right]$.

Calculated GE content was highly correlated with GE measured by bomb calorimetry (Pearson $\mathrm{r}=$ 0.982). Passing-Bablok regression of calculated versus measured GE produced a slope and intercept that did not differ from 1 and 0 , respectively (Figure 3). Mean predicted $(21.08 \pm 0.78 \mathrm{~kJ} / \mathrm{g}$ of $\mathrm{WM})$ and measured $(21.08 \pm 0.78 \mathrm{~kJ} / \mathrm{g}$ of WM) energy content of milk were not significantly different (Table 1), being virtually identical. Predictive performance was good, as indicated by low MRE, RMSE, and high PRESS $\mathrm{r}^{2}$ (Table 2). A pooled sample of Weddell seal milk fat had a measured GE content of $38.2 \mathrm{~kJ} / \mathrm{g}$, very close to the factor of $38.1 \mathrm{~kJ} / \mathrm{g}$ used in GE calculations. 

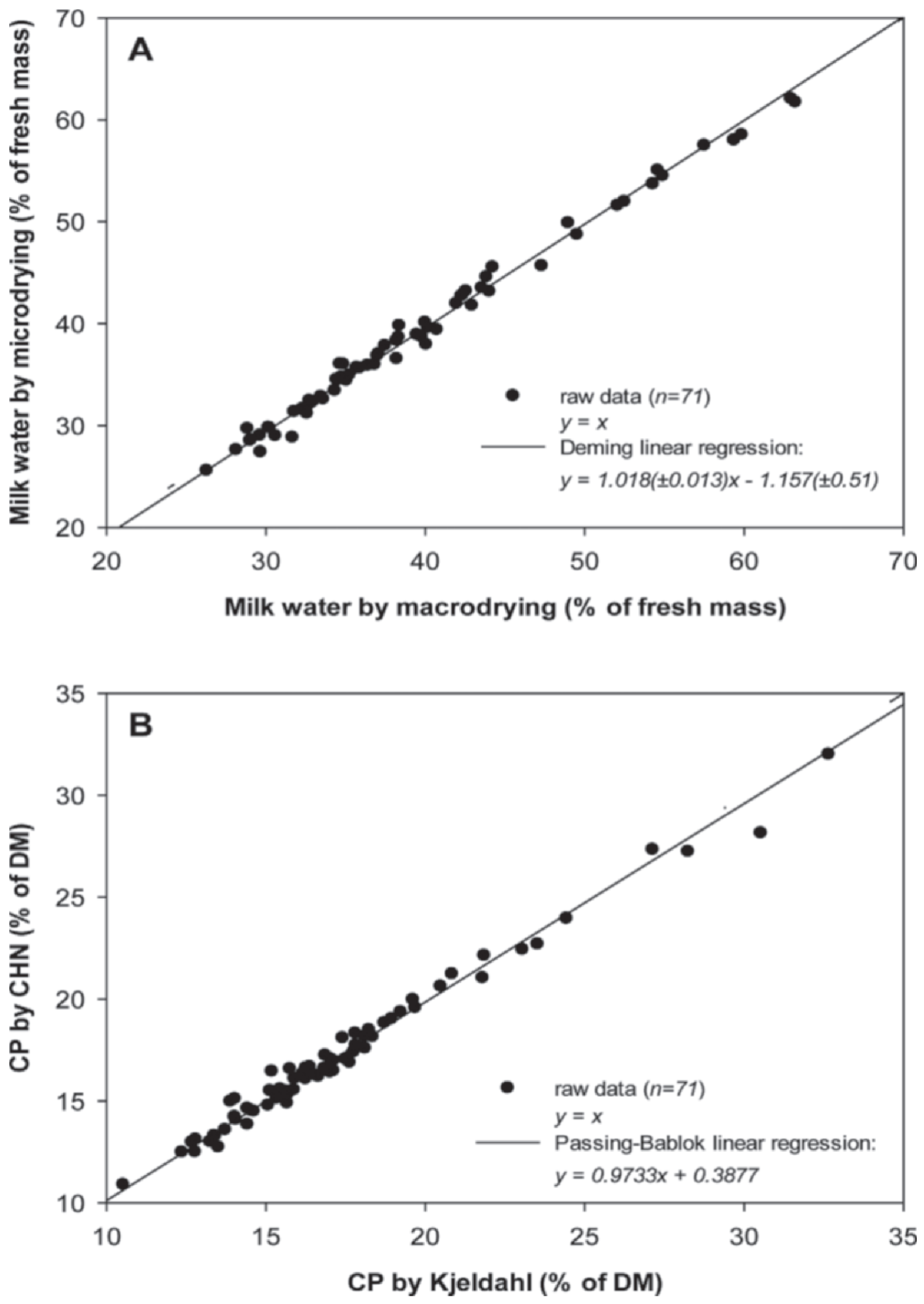

Figure 1. Comparison of alternative versus reference methods for analysis of Weddell seal milk. (A) Water content: microdrying versus reference drying at $100^{\circ} \mathrm{C}$; (B) $\mathrm{CP}$ content: Dumas (carbon-hydrogen-nitrogen, $\mathrm{CHN}$ ) gas analysis versus macro-Kjeldahl procedure $($ total $\mathrm{N} \times 6.38$ ) Results are expressed as mass percentage. 
Table 1. Comparison between different methods ${ }^{1}$ of milk analysis

\begin{tabular}{|c|c|c|c|c|c|c|}
\hline Item $^{2}$ & $\begin{array}{l}\text { Water } \\
\text { microdrying vs. } \\
\text { reference drying } \\
\text { (\% of wet mass) }\end{array}$ & $\begin{array}{c}\text { CP Dumas/CHN } \\
\text { vs. Kjeldahl } \\
\text { ( } \% \text { of DM) }\end{array}$ & $\begin{array}{c}\text { Fat } \\
\text { stoichiometric vs. } \\
\text { Röse-Gottlieb } \\
\text { (\% of OM) }\end{array}$ & $\begin{array}{c}\text { Fat } \\
\text { microgravimetric vs. } \\
\text { Röse-Gottlieb } \\
\text { (\% of wet mass) }\end{array}$ & $\begin{array}{c}\text { Sugar } \\
\text { stoichiometric } \\
\text { vs. phenol-sulfuric } \\
(\% \text { of OM })\end{array}$ & $\begin{array}{l}\text { Calculated GE vs. } \\
\text { bomb calorimetry } \\
\text { (kJ/g of wet mass) }\end{array}$ \\
\hline Number of samples & 71 & 71 & 47 & 47 & 47 & 20 \\
\hline \multicolumn{7}{|l|}{ Correlation } \\
\hline Pearson $\mathrm{r}$ & 0.996 & 0.992 & 0.867 & 0.991 & 0.433 & 0.982 \\
\hline Significant? & Yes & Yes & Yes & Yes & Yes & Yes \\
\hline \multicolumn{7}{|l|}{ Regression } \\
\hline type & wDLR & PBR & PBR & PBR & PBR & PBR \\
\hline Slope (a) & 1.02 & 0.973 & 1.05 & 0.973 & 14.5 & 1.02 \\
\hline Intercept (b) & -1.16 & 0.388 & -0.233 & 1.62 & -21.9 & -0.232 \\
\hline $\mathrm{a} \neq 1.0$ & NS & NS & NS & NS & & NS \\
\hline$b \neq 0$ & $0.02<P<0.05$ & NS & NS & NS & & NS \\
\hline \multicolumn{7}{|l|}{ Comparison } \\
\hline$y$, mean \pm SEM & $38.7 \pm 1.1$ & $17.2 \pm 0.46$ & $83.1 \pm 0.83$ & $48.7 \pm 1.4$ & $-0.30 \pm 0.44$ & $21.1 \pm 0.78$ \\
\hline$x$, mean \pm SEM & $39.2 \pm 1.1$ & $17.3 \pm 0.49$ & $80.3 \pm 0.78$ & $48.5 \pm 1.4$ & $1.61 \pm 0.08$ & $21.1 \pm 0.78$ \\
\hline Test & Paired $t$-test & WSRT & Paired $t$-test & WSRT & & Paired $t$-test \\
\hline$P$-value & 0.001 & 0.253 & $<0.001$ & 0.15 & & 0.987 \\
\hline \multicolumn{7}{|l|}{ Predictive performance } \\
\hline RMSE & 0.94 & 0.54 & 4.0 & 1.3 & 3.4 & 0.65 \\
\hline Relative error, $\% x$ (range) & -1.4 & -0.54 & 4.2 & $\begin{array}{l}0.3 \\
\left(-123+0^{2}\right.\end{array}$ & -153 & 0.65 \\
\hline PRESS $r^{2}$ & $\begin{array}{c}(-9.0 \text { to } 4.0) \\
0.989\end{array}$ & $\begin{array}{c}(-7.8 \text { to } 8.3) \\
0.982\end{array}$ & $\begin{array}{c}(-4.6 \text { to } 11.6) \\
0.417\end{array}$ & $\begin{array}{c}(-12.3 \text { to } 9.3) \\
0.981\end{array}$ & $<0.00$ & $\begin{array}{c}(-7.0 \text { to } 5.0) \\
0.963\end{array}$ \\
\hline
\end{tabular}

CHN = carbon-hydrogen-nitrogen (Dumas method); OM = ash-free OM; GE = gross energy.

${ }^{2} \mathrm{wDLR}=$ weighted (proportional) Deming linear regression; PBR = Passing-Bablok regression; variable $y$ is the alternative method or prediction (first named of each method pair); variable $x$ (second named) is the reference method; WSRT $=$ Wilcoxon signed-rank test; RMSE $=$ root of mean squared error; PRESS $\mathrm{r}^{2}=$ prediction sum of squares. 

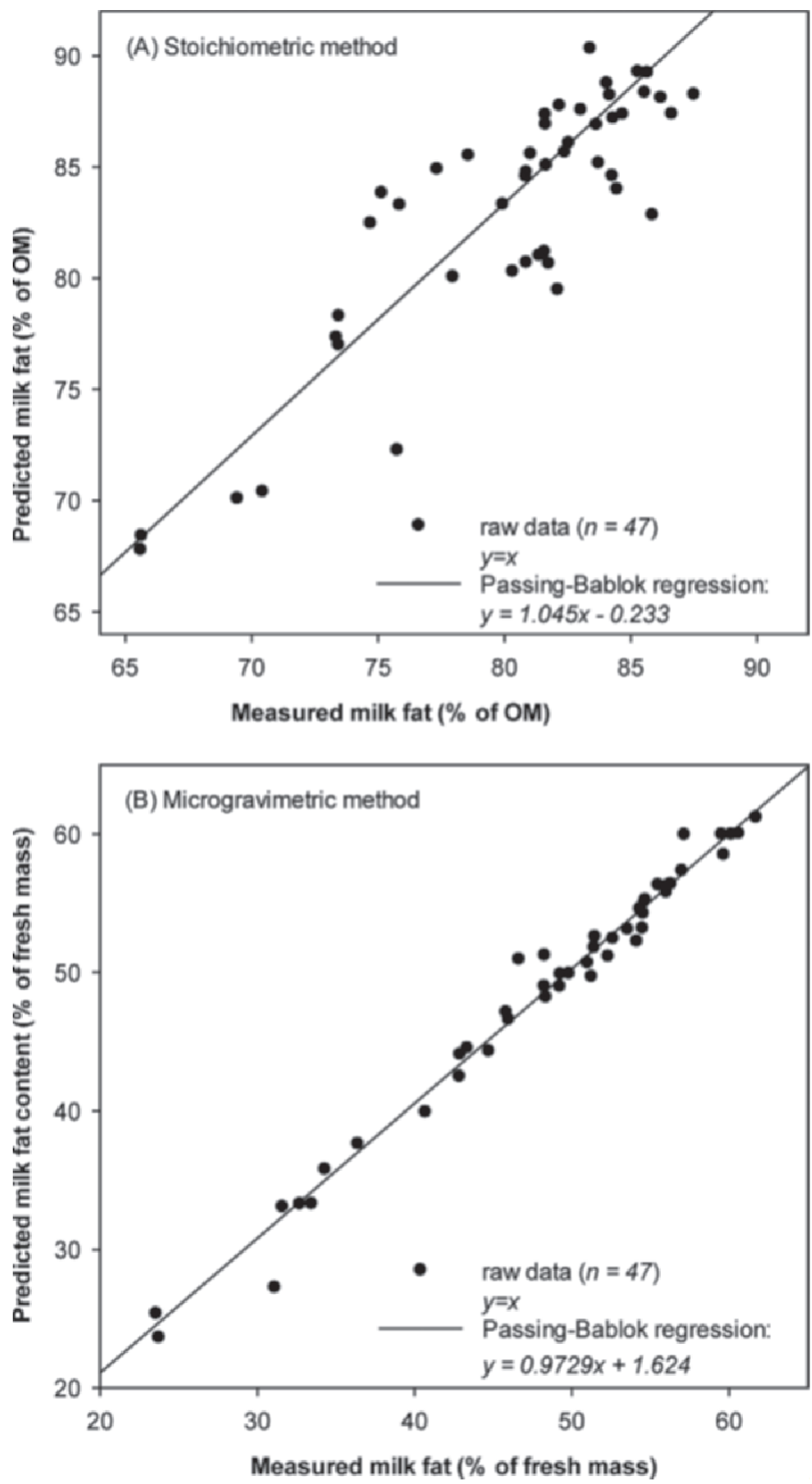

Figure 2. Predicted versus measured fat content of Weddell seal milk. (A) Stoichiometric prediction method versus fat measured by the Röse-Gottlieb method; (B) microgravimetric prediction method versus fat measured by the Röse-Gottlieb method. See text for details of each prediction method.

\section{DISCUSSION}

\section{Method Validation}

Reference methods are essential for quantitative laboratory work (Wehr, 2004), and are especially important in comparative research, where differences among studies that use different methods could be due to biological variation or may just reflect different methodological

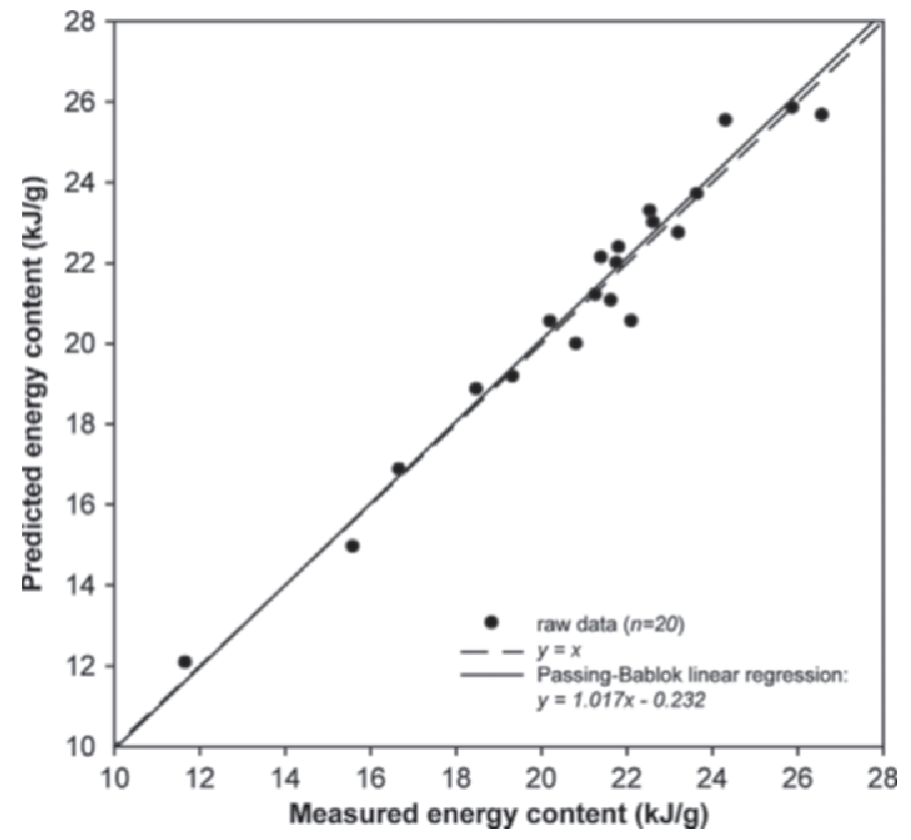

Figure 3. Predicted versus measured gross energy (GE) content of Weddell seal milk. Gross energy was predicted from the factors of $38.1,24.5$, and $16.5 \mathrm{~kJ} / \mathrm{g}$ for fat, CP, and sugar, respectively, and was measured by adiabatic bomb calorimetry.

biases and errors. Any attempts to model nutrient fluxes of marine mammals during lactation (e.g., Oftedal, 1993; Mellish et al., 2000; McDonald and Crocker, 2006; Lang et al., 2009) or to understand factors that influence phylogenetic patterns in milk composition (e.g., Oftedal et al., 1987; Oftedal and Iverson, 1995; Oftedal, 1997; Schulz and Bowen, 2004, 2005; Ferguson, 2006) are only as valid as the compositional data on which models are based.

An alternative method can be inadequate even with a high correlation coefficient; for example, when there is a systematic difference between reference and alternative methods (Sheiner and Beal, 1981). It is a necessary but not sufficient condition that the alternative and reference methods applied to the same samples produce equivalent mean values by paired comparisons. Even a paired comparison test can be misleading, as when there is a proportional (slope $\neq 1$ ) or mixed proportional-additive (slope $\neq 1$ and intercept $\neq 0$ ) difference in the results of 2 methods (Linnet, 1999), and this may only be evident if the methods are compared using regression analysis (Linnet, 1993; Stöckl et al., 1998). In addition, if repeatability of an assay is poor, the large error term may result in wide confidence intervals for slope and intercept estimates that include 1 and 0 , respectively, and thus disguise method differences. This is one reason that a highly repeatable reference method is so important in method validation (Lynch and Barbano, 1999). 
Table 2. Estimated residual sulfuric acid after Kjeldahl digestion of marine mammal milks ${ }^{1}$

\begin{tabular}{|c|c|c|c|c|c|c|c|c|}
\hline \multirow{2}{*}{ Species } & \multirow{2}{*}{\multicolumn{3}{|c|}{ Milk composition $^{2}(\%)$}} & \multirow{2}{*}{\multicolumn{2}{|c|}{ Protein multiple $^{3}$}} & \multicolumn{3}{|c|}{ Residual $\operatorname{acid}^{4}(\mathrm{~g})$} \\
\hline & & & & & & \multicolumn{2}{|c|}{ Initial $=44 \mathrm{~g}$} & $\frac{\text { Initial }=53 \mathrm{~g}}{2 \mathrm{~g} \text { of milk }}$ \\
\hline Cow & 3.8 & 3.3 & 5 & 1.0 & & 27 & & \\
\hline Bottlenose dolphin & 12.8 & 8.9 & 1 & 2.7 & 1.1 & 18 & 28 & \\
\hline Caribbean manatee & 14.8 & 8.1 & 0.4 & 2.5 & 1.0 & 17 & 27 & \\
\hline California sea lion & 43.7 & 8.9 & 0.6 & 2.7 & 1.1 & -10 & 17 & \\
\hline Weddell seal & 54.0 & 10.2 & 0.8 & 3.1 & 1.2 & -20 & 13 & 21 \\
\hline Hooded seal & 61.1 & 4.9 & 1 & 1.5 & 0.6 & -24 & 11 & 20 \\
\hline
\end{tabular}

${ }^{1}$ Residual acid calculated based on initial delivery of $25 \mathrm{~mL}(44 \mathrm{~g})$ or $30 \mathrm{~mL}(53 \mathrm{~g})$ of sulfuric acid and either 5 or $2 \mathrm{~g}$ of milk. Digestion was assumed to consume 18, 9, and $7 \mathrm{~g}$ of acid per gram of fat, protein, and sugar, respectively (Lynch and Barbano, 1999), losses due to volatilization were assumed to be $4.4 \mathrm{~g}$, and acid required to convert potassium sulfate to acid sulfate was assumed to be $5.6 \mathrm{~g}$ (Bradstreet, 1965).

${ }^{2}$ Milk composition data from Oftedal and Iverson (1995), Oftedal (2011), and Eisert et al. (2013).

${ }^{3}$ Protein multiple, calculated as total $\mathrm{N}$ (TN) in sample/TN in $5 \mathrm{~g}$ of cow's milk, provides an index of the titration volume required.

${ }^{4}$ Bolded values indicate that residual acid was too low ( $\left.<15 \mathrm{~g}\right)$, with potential $\mathrm{N}$ loss (Bradstreet, 1965).

At a minimum, a methods comparison should involve replicate analyses of the same samples by the methods to be compared. A sufficient number and spectrum of samples should be included to encompass the expected range of analyte concentration. We recommend 4 basic requirements to ensure equivalence of 2 analytical methods: (1) excellent linear correlation of paired results (e.g., Pearson $\mathrm{r}>0.95$ ); (2) a nonsignificant paired comparison test; (3) linear regression with slope and intercept parameters that do not differ from 1 and 0 , respectively, using a regression procedure that takes into account errors in both dependent $(y)$ and independent $(x)$ variables (e.g., Passing and Bablok, 1983; Linnet, 1993); and (4) adequate predictive performance for samples that are representative of the population (e.g., relative error range -10 to $+10 \%$, RMSE $\leq 2 \%$ of mean value, PRESS $\left.r^{2}>0.95\right)$.

An additional concern in formal adoption of analytic methods for milk analysis is interlaboratory reproducibility (Peeler et al., 1989) but that is beyond the scope of the present single-laboratory project. Some analytical methods are indirect assays in that they require calibration against reference material that is assayed by a reference method (Tremblay et al., 2003). Any samples used for calibration are not suitable for validation, which requires testing of independent samples by the methods being compared.

\section{DM by Reference and Microdrying Procedures}

Any drying procedure is a compromise between removal of residual water and creation of artifacts due to heating. Depending on drying temperature, time, and oven vapor pressure, some residual water remains in dried cow milk samples as $\alpha$-lactose monohydrate crystals or in other constituents, some water is generated from organic constituents due to condensation reactions (such as when reducing sugars react with lysine and $N$-terminal AA in a Maillard reaction), and some volatile organic constituents are generated and escape during heating (Holsinger, 1988; Clark et al., 1989; van Boekel, 1998; Isengard et al., 2006). The assumption that drying to constant mass at any temperature gives an accurate measure of milk water content is incorrect: the "constant mass" at lower temperatures inevitably includes greater residual water, which is a particular problem in lyophilized material (Seligmann and Farber, 1971; Isengard et al., 2006). Where precise determination of residual water is essential, as when assessing moisture in reference standards and spray-dried milk powders (Rückold et al., 2001), water may need to be determined directly, such as by Karl-Fischer titration, because there is no means to remove all water in dried milk samples without causing degradative changes that also generate artifactual weight loss (Reh et al., 2004; Isengard et al., 2006). However, this is not practical for routine milk analysis.

The reference method of drying at $100^{\circ} \mathrm{C}$ for $4 \mathrm{~h}$ for cow milk seeks to minimize both residual water and browning reactions (Hooi et al., 2004). Drying at $100^{\circ} \mathrm{C}$ is also the most widely used regimen for marine mammal milks (about half of 49 studies for which drying temperature was reported; temperatures ranged from 60 to $\left.105^{\circ} \mathrm{C}\right)$, although the range of drying times (3-96 h) has been large. Sample mass is important, because it affects residual water, but is rarely reported. In our experience, small milk samples dry more quickly and brown to a greater degree than larger samples, and thus 
have different "dry weights," even when dried at the same temperature and for the same time (Hood et al. 2009). We dried 1-g samples of marine mammal milks for $4 \mathrm{~h}$ as this generates a comparable DM $(\sim 0.3-0.7$ g) to the reference method that specifies 2 to $3 \mathrm{~g}$ of cow milk or cream $(\sim 0.25-0.85 \mathrm{~g}$ of $\mathrm{DM})$. With frozenthawed Weddell seal milk, the repeatability $\left(\mathrm{RSD}_{\mathrm{r}}=\right.$ $0.62 \%$ ) was acceptable for a reference drying procedure, although higher than for fresh cow milk $\left(\mathrm{RSD}_{\mathrm{r}}=0.15 \%\right.$; Wehr, 2004); this discrepancy may be due to difficulties in homogenization of frozen-thawed milk

Our alternative microdrying method was a preparatory step for Dumas (CHN) analysis, and used much smaller subsamples $(2.5-4 \mathrm{mg})$ in narrow fluted tin vials that serve as catalytic material when subsequently combusted in CHN analysis. Following Hood et al. (2009), these small subsamples were dried at $100^{\circ} \mathrm{C}$ for $2.5 \mathrm{~h}$. In a study of killer whale (Orcinus orca) milk, we observed co-variation in DM and C percentage among such small replicates that we attributed to variation in the amount of fat in subsamples (O. T. Oftedal and S. Clark, SeaWorld Parks and Entertainment, Orlando, FL, unpublished data); to account for such potential variation, the number of sample replicates was increased $(\mathrm{n}=7)$. With careful mixing and subsampling, lack of homogeneity did not prove to be a major problem for Weddell seal milk; the $\mathrm{RSD}_{\mathrm{r}}$ was only moderately increased $(0.93 \%)$ compared with the reference method $(0.62 \%)$. When expressed as water content, the micro-drying method gave a high correlation (Pearson $\mathrm{r}=0.994$ ) and slope not different from 1 , relative to the reference method (Figure 1A), but the small but significant intercept indicated a constant (additive) error requiring a corresponding correction. A plot of the residual difference between methods (micro-DM - macro-DM) against the reference method (macro-DM) did not reveal any statistical trend other than the mean (constant) difference (data not shown). We assume this error stems from the narrow shape of the tin vials, which would have minimized air flow at the surface; the narrow vial shape may also allow lipid to layer over the top, trapping residual moisture. Wide, flat-bottomed aluminum pans are recommended for drying milk (Hooi et al., 2004).

The significant discrepancy of these 2 drying methods, both at $100^{\circ} \mathrm{C}$, illustrates the importance of the details of drying methods that are rarely reported. Given the importance of residual water for stoichiometric procedures (Gnaiger and Bitterlich, 1984) and for isotopic measurements of milk production (Oftedal and Iverson, 1987), laboratory parameters that may influence measured water content should be carefully selected and reported. The great variety of drying procedures used in marine mammal studies has undoubtedly introduced procedural bias but the magnitude of such bias cannot at present be determined.

\section{CP by KjeldahI Versus CHN/Dumas Method}

For milk and dairy products, the reference method for protein determination is the macro-Kjeldahl method (Lynch and Barbano, 1999; Tremblay et al., 2003); micro-Kjeldahl methods do not have reference status because of their increased replicate variability (high $\mathrm{RSD}_{\mathrm{r}}$ ). Earlier modifications of the macro-Kjeldahl method have been resolved into a single approved method for cow milk with specified amounts of sample, sulfuric acid, potassium sulfate, and catalyst, and designated boil times (Barbano et al., 1990; Lynch and Barbano, 1999; Hooi et al., 2004). The 6.38 multiplication factor of $\mathrm{TN}$ to $\mathrm{CP}$ remains a convention, as the $\mathrm{N}$ content varies somewhat among individual milk proteins (Tremblay et al., 2003) but is generally accepted in marine mammal studies (47 of 48 studies that specified a factor). True protein can be determined via Kjeldahl analysis of $\mathrm{TN}$ and subtraction of NPN, or by direct determination of precipitated milk proteins (Barbano et al., 1991).

Micro- and macro-adaptations of the Kjeldahl method are commonly used in marine mammal milk studies, accounting for about $70 \%$ of the post- 1960 publications ( $\mathrm{n}=78$ ) we have seen. Unfortunately, information is rarely given on sample size, catalyst, amounts of potassium sulfate and sulfuric acid, type of heating system (block digester vs. individual heaters) or post-clear boil times, all of which influence assay performance (Lynch and Barbano, 1999). Nitrogen recoveries, repeatability of replicates, and assay of standard reference materials are important performance criteria, but are not usually reported. Although such omissions are not unique to marine mammal studies (Lynch and Barbano, 1999), the high fat content of marine mammal milks is likely to interfere with Kjeldahl analysis because, during digestion, fat consumes about twice the amount of acid (18-19 g per g) as does protein (8-10 g per g) or sugar (7-8 g per g), and if insufficient residual acid remains at the end of digestion, nitrogen may be lost (Bradstreet, 1965). Table 2 presents estimated residual acid amounts after digestion of various amounts and types of marine mammal milk. Whereas 5 -g samples (as specified for cow milk; Hooi et al., 2004) are appropriate for samples with a fat content $<15 \%$, sample size must be reduced for higher fat milks to ensure sufficient acid is available to complete digestion and prevent $\mathrm{N}$ loss. For most marine mammals, the appropriate sample size is $\sim 2 \mathrm{~g}$ to maintain residual acid $>15 \mathrm{~g}$ (Table 2). Sample reduction also reduces titration volume, which is proportional to the amount of $\mathrm{N}$ 
in the sample (expressed in Table 2 as multiples of the $\mathrm{N}$ in $5 \mathrm{~g}$ of cow milk).

True seal milks commonly contain more than $45 \%$ fat; thus, digestion of $2 \mathrm{~g}$ of milk leaves insufficient residual acid (Table 2), but further reduction in sample size compromises $\mathrm{N}$ determination due to the relatively low protein content in milks of some species, such as hooded seals (Table 2). In analyzing hooded seal (Cystophora cristata) milk, a higher initial acid volume (30 vs. $25 \mathrm{~mL}$ ) was therefore adopted (Table 2; Oftedal et al., 1988; O. T. Oftedal, unpublished data). Although an increase in the ratio of sulfuric acid to potassium sulfate reduces initial boil temperature (Bradstreet, 1965), the large acid consumption during digestion results in a mass ratio of acid:salt of 2:1 at the end of digestion, which is close to the recommended value of $1 \mathrm{~mL}$ of acid per $\mathrm{g}$ of added salt ( $=1.8: 1$ by mass; Case et al., 1985). To analyze 1-g samples of Weddell seal milk, we used $30 \mathrm{~mL}$ of sulfuric acid, which left ample residual acid; $\mathrm{N}$ recovery (when ammonium sulfate was added) was $100 \%$ and triplicate $\mathrm{RSD}_{\mathrm{r}}$ was $0.60 \%$. For comparison, interlaboratory studies of the Kjeldahl method using cow milk report $\mathrm{RSD}_{\mathrm{r}}$ values of 0.39 to $0.65 \%$ (Wiles et al., 1998). The TN of the NIST whole milk standard (assayed with $25 \mathrm{~mL}$ of sulfuric acid) was at $99 \%$ of the declared value and within target limits. We did not test use of additional potassium sulfate, which would have increased initial boiling temperature, or variation in catalyst amounts. Thus, for phocid milks, we recommend 1- to 2-g samples and use of $30 \mathrm{~mL}$ of sulfuric acid, although $25 \mathrm{~mL}$ of acid may be sufficient for samples with $<45 \%$ fat. However, a larger volume of acid used with lower-fat samples (as may occur during early or late lactation; Oftedal, 1997, 2011) can produce extreme heating and boil-over during mixing of acid and base at the start of distillation (O. T. Oftedal and R. Eisert, unpublished data); thus, for such samples, either acid volume should be decreased or sample size increased.

In the alternative method - the modified Dumas (CHN) combustion method - all forms of sample $\mathrm{N}$ are converted to $\mathrm{N}$ oxides $\left(\mathrm{NO}_{\mathrm{x}}\right)$ in a combustion chamber, reduced to $\mathrm{N}_{2}$ gas in a reduction chamber, and then measured by thermal conductivity (Simonne et al., 1997). The Dumas method includes $\mathrm{N}$ in compounds (such as nucleic acids, nitrates, and nitrites) that are incompletely recovered by typical Kjeldahl procedures, but these compounds occur only as traces in milk. For cow milk (fresh, dry, skim, or low fat), Dumas N averages between 97 and $103 \%$ of Kjeldahl N (Simonne et al., 1997; Etheridge et al., 1998; Wiles et al., 1998; ISOIDF, 2002; Thompson et al., 2002). Although there was no mean difference between methods, when Etheridge et al. (1998) regressed Kjeldahl against Dumas results, the slope was significantly less than 1 (0.815) and the intercept greater than 0 , suggesting presence of both constant and proportional errors. However, discrepancies in these and other method comparisons may as much reflect lack of standardization of Kjeldahl procedures as a true discrepancy between Dumas and Kjeldahl methods, making interpretation difficult (Lynch and Barbano, 1999).

Given the high fat content of Weddell milk samples, we restricted CHN sample size to $4 \mathrm{mg}$ of WM or less, increased furnace temperature to $950^{\circ} \mathrm{C}$, and included supplemental oxygen boosts to ensure complete combustion. Other than the higher $\mathrm{RSD}_{\mathrm{r}}$ in $\mathrm{CHN} /$ Dumas $(1.56 \%)$ compared with macro-Kjeldahl $(0.60 \%)$ results, the 2 methods produced almost identical results: we found no significant difference in mean values $(17.2 \%$ vs. $17.3 \%$ CP in DM), the slope and intercept of Dumas versus Kjeldahl (Figure 1B) were not significantly different from 1 and 0 , respectively, the RMSE was low, and the PRESS $\mathrm{r}^{2}$ was above the 0.95 threshold (Table 1). We conclude that CHN/Dumas is a suitable alternative CP method for marine mammal milks, as long as sample size and combustion parameters are appropriate to the sample material. One caveat is the possibility of poor homogeneity among replicates given their very small mass and difficulties in keeping fat uniformly dispersed in frozen-thawed marine mammal milks. We observed this difficulty during analysis of killer whale milk (see above) but not in a bottlenose dolphin study (West et al., 2007). The higher $\mathrm{RSD}_{\mathrm{r}}$ for the Dumas method suggests that additional replicates are warranted. We recommend analyzing 4 or more replicates per sample so that variance due to poor mixing can be identified.

The Kjeldahl and CHN/Dumas methods measure TN, unless separate NPN or protein N assays are performed. In Weddell seal milk, NPN accounted for about $4 \%$ of TN compared with 3 to $7 \%$ in several fur seals and sea lions (Oftedal et al., 1987), 9\% in southern elephant seals (Mirounga leonina; Carlini et al., 1994) and from 5 to $11 \%$ in various cetaceans (calculated from data in Oftedal, 1997). Thus, we would expect both Kjeldahl and CHN/Dumas to overestimate protein $\mathrm{N}$ by about 3 to $12 \%$ in marine mammals. The constituents producing high milk NPN in both terrestrial (Oftedal, 1984) and marine carnivores are unknown, but may reflect urea or other products of protein catabolism in species on low-carbohydrate diets that utilize protein AA for gluconeogenesis (see Eisert, 2011).

\section{Other Protein Methods for Analysis of Marine Mammal Milks}

Various other methods have been used for estimation of protein in marine mammal milks, including 
dye-binding/Bradford (Pervaiz and Brew, 1986), biuret (Baker, 1990), Lowry (Hedberg et al., 2011), and nesslerization (Gamel et al., 2005) procedures, usually without validation. These methods are suspect. The results of dye-binding assays are proportional to dye-binding capacity, which differs among milk proteins (Tremblay et al., 2003) and across species (Colenbrander and Martin, 1971). The Bradford (1976) method has been reported to underestimate Kjeldahl CP by 16,19 , and $31 \%$ in cow, human, and pig milks, respectively (Keller and Neville, 1986; Atwood and Hartmann, 1992; Kamizake et al., 2003). The biuret method is subject to interferences that generate variance in results independent of protein content (Verheul et al., 1986; Sapan et al., 1999). The biuret method reportedly overestimates Kjeldahl protein by 44 and $73 \%$ in cow and human milk, respectively (Keller and Neville, 1986; Kamizake et al., 2003). Color development in the Lowry method is strongly influenced by constituent AA such as tyrosine and tryptophan so that assay response is highly protein-specific; the assay is also subject to interferences (Sapan et al., 1999). The Lowry protein was similar to Kjeldahl protein in pig milk, was higher by $9 \%$ in cow milk (but this was not significant), and was $32 \%$ greater than Kjeldahl protein in human milk (Keller and Neville, 1986; Atwood and Hartmann, 1992; Kamizake et al., 2003). Kretzmann et al. (1993) attribute a large constant error in earlier Lowry data on Northern elephant seal (Mirounga angustirostris) milk to use of an inappropriate standard, but no formal methods comparison was attempted. Nessler's procedure (Koch and McMeekin, 1924) shares with the CHN/Dumas method high sensitivity and small sample amount, but accurate and repeatable results depend on uniform timing in heating and cooling of samples and standards that is hard to achieve in practice and commonly results in operator bias (Hood et al., 2009). In the only recent application of this method to marine mammal milks, Gamel et al. (2005) increased the amount of hydrogen peroxide and the duration of heating to compensate for high fat content, but did not indicate how or if the method was validated.

Differences in results among protein methods may be more than just a shift in mean values. Keller and Neville (1986) compared methods for human milk protein by linear regression against Kjeldahl protein. The slopes for the Bradford (0.83) and biuret (0.79) methods were significantly different from 1 ; the biuret (but not the Bradford) also has a significant $(>0)$ intercept. The Lowry slope (1.03) did not differ from 1, but its intercept was significant $(>0)$. Keller and Neville (1986) considered the constant error as due to interferences and the proportional error (slope $<1$ ) as indicative of differing assay responses to milk proteins. In Weddell seals, milk protein measured by a modified Lowry was very low $(5 \%)$ in early lactation and very high $(15 \%)$ in late lactation (Wheatley et al., 2008). In contrast, we found little change over lactation in milk CP content by a macro-Kjeldahl method (Eisert et al., 2013), nor do the Dumas (CHN) results reported herein demonstrate such a pattern (data not illustrated). Such Lowry data may represent uneven sensitivity to individual proteins secreted at different times, may be a response to interfering compounds, or might reflect metabolic alteration of milk composition due to effects of immobilizing drugs or environmental factors. Unfortunately, it is not possible to separate analytical errors from biological effects when an unvalidated method, such as Lowry, is utilized. The Bradford, biuret, or Lowry methods do not appear suitable for analysis of mammalian milks and thus should not be used unless their validity can be demonstrated for the target species.

Infrared (IR) analysis is widely used in the dairy industry for milk protein analysis, either using absorbance in the mid-IR spectrum or reflectance in the near-IR spectrum (Tremblay et al., 2003). Calibration is paramount in IR methods (Barbano and Clark, 1989; Hooi et al., 2004); Albanell et al. (2003) used more than 130 milk samples in calibrating a near-IR system for goat milk. Riet-Sapriza et al. (2009) used Kjeldahl results to calibrate a mid-IR instrument for New Zealand sea lion (Phocarctos hookeri) milk, and then attempted to validate the method with independent samples. Although mean protein concentration was $95 \%$ of Kjeldahl CP, the correlation between paired results was low $(\mathrm{r}=0.79)$. We re-examined the graphed data via our criteria. A Passing-Bablok regression fitted to the data had a low slope (0.647) and large intercept (2.5) but these did not differ from 1 and 0 , respectively. However, the relative error was large (RMSE $=1.3$, equivalent to $13 \%$ of the mean) and predictive performance was poor (PRESS $\left.r^{2}=0.54\right)$. Both milk fat and sugar (lactose) interfere with absorbance in the mid-IR wavelength range used for protein determination, necessitating the use of correction factors (Tremblay et al., 2003). Although sea lion milks are devoid of lactose (Oftedal, 2011 ), it is possible that large variation in fat content (14-37\% fat on WM basis) in Riet-Sapriza et al. (2009) samples affected the instrument response in ways that could not be accounted for, given that just 10 calibration samples were used. Mid- and near-IR analyses may yet prove valuable for marine mammal milks, but they will require further validation, including testing of absorbance interference by marine mammal milk constituents at different sample and reference wavelengths, before they can be used reliably (contra Riet-Sapriza et al., 2009, 2012). 


\section{The Carbon Stoichiometry Method for Estimating Fat and Sugar}

Arnould et al. (1995) proposed that direct analysis of milk fat could be replaced by a predictive procedure based on carbon stoichiometry using CHN data. If the carbon contents of fat, protein, and carbohydrate are fixed as input factors, and the $\mathrm{C}$ content of protein in a sample is estimated from $\mathrm{N}$ analysis (using an assumed $\mathrm{C}: \mathrm{N}$ ratio and correcting for $\mathrm{NPN}$ ), the $\mathrm{C}$ content of the nonprotein $\mathrm{OM}$ can be assumed to reflect the relative proportions of fat and carbohydrate (Gnaiger and Bitterlich, 1984). This is theoretically feasible, due to the large disparity in $\mathrm{C}$ contents of fat (measured as $74.35 \%$ in fat extracted from Weddell seal milk) and carbohydrate (estimated as $43.79 \%$ for Weddell seal milk sugars). However, despite our best efforts to accurately determine species-specific input factors, the correspondence between stoichiometric fat estimates and Röse-Gottlieb results was poor (Figure 2A). The Pearson correlation coefficient $(\mathrm{r}=0.867)$, though significant, was lower than acceptable, the predicted fat was significantly higher than measured fat $(83.3 \%$ vs. $80.3 \%$ of OM; Table 2), and the PRESS $\mathrm{r}^{2}$ was only 0.417 , indicating poor predictive performance. The scatter of the data is apparent in Figure 2A.

Differences between our approach and that of Arnould et al. (1995) are that we measured carbon directly in extracted fat (rather than using data for $1 \mathrm{FA}$ ), calculated a $\mathrm{C}: \mathrm{N}$ ratio based on all milk proteins (not just casein), used species-specific data for the NPN correction (rather than assuming similarity to the southern elephant seal), and estimated residual moisture in the dried material used for $\mathrm{CHN}$ analysis via comparison to reference drying (rather than make an assumption). Gnaiger and Bitterlich (1984) applied a $6 \%$ moisture correction in analysis of dried fish tissues, gut contents, and feeds, and this correction factor was adopted by Arnould et al. (1995) for fur seal milk. However, oven-dried cow milk powder contains only $0.39 \%$ water, as measured by Karl Fischer titration, primarily due to $\alpha$-lactose monohydrate crystals (Reh et al., 2004); our $0.74 \%$ correction (based on the observed mean difference between macro- and micro-dried samples) is close to the value for cow milk and therefore appears more likely than the Gnaiger and Bitterlich (1984) value of $6 \%$. The additional data and improved estimates we applied did not sufficiently improve predictive performance. Arnould et al. (1995) found that predicted fat was not strongly correlated $(\mathrm{r}=0.79)$ to measured fat; we found the same. They observed a significant difference (paired $t$-test, $P<0.0005$ ) between predicted $(41.6 \%)$ and measured $(45.1 \%)$ fat, although their approach underestimated, and our approach over- estimated, measured fat. However, the Bligh and Dyer method of fat analysis used by Arnould et al. (1995) may not be accurate for marine mammal milks (see below). We conclude that carbon stoichiometry is, at present, neither sufficiently accurate nor does it have satisfactory predictive performance to be acceptable for marine mammal milks.

The stoichiometric method requires complex calculations and assumptions about the constancy of the $\mathrm{C}$ content of constituents (Gnaiger and Bitterlich, 1984). For comparison, we also predicted fat by a simple microgravimetric method that is based on microdrying, Dumas (CHN) nitrogen, and an empirical constant (Figure 3B). With this procedure, (1) predicted fat was tightly correlated to measured fat, (2) the slope and intercept of the regression were not different from 1 and 0 , respectively, (3) the difference between the 2 sets of results was not significant, and (4) the PRESS $r^{2}$ was very high (Table 2). Note that the constant is derived from the same samples as those for which fat was predicted; full validation would require this predictive procedure to be tested with a completely independent set of samples. However, the primary motivation was not to propose an alternative method of fat analysis, but to provide comparative data to assess the performance of the stoichiometric method. Although the microgravimetric method had high accuracy and predictive performance for our samples, we recommend analyzing marine mammal milks by standard methods (Röse-Gottlieb/Mojonnier) and caution against use of any calculation that determines a constituent by difference from the results of other assays. It is important that the errors associated with such assays be minimal, or they may have a disproportionate effect on what is estimated by difference. In our study, the sum of analyses of water, fat, CP, sugar, and ash accounted for $>99 \%$ of milk mass, suggesting errors were minor, counteracting, or both.

The underlying assumption of our comparisons is that the Röse-Gottlieb procedure entails a quantitative extraction of milk fat. In marine and other mammals, milk fat is secreted as milk fat globules (MFG) enveloped in glycoprotein-rich bilayer membranes that aid in the formation of a stable emulsion (Tedman, 1983; Mather, 2011). Milk fat is usually analyzed in whole milk, using a reagent combination that disrupts MFG, prevents gel formation (i.e., failure of layers to separate), and extracts lipids into a nonpolar solvent layer. The Röse-Gottlieb method and its modification, the Mojonnier method, have long been considered the reference procedures for fat measurement in milk and cream (Case et al., 1985; Hooi et al., 2004). In both methods, milk is initially treated with ammonium hydroxide and ethanol, followed by repeated sequential 
extractions with increasingly nonpolar solvents (diethyl ether and petroleum ether), with vigorous shaking to ensure lipid recovery. Phase separation occurs either upon standing (Röse-Gottlieb) or after centrifugation (Mojonnier), allowing the upper ether layer to be drawn off into a collection pan and volatilized. The ether-extracted material is measured directly (Mojonnier) or by difference before and after removing lipids from the pan with hot petroleum ether (Röse-Gottlieb). The Mojonnier fat extract includes small amounts of residue that remain in the pan in the Röse-Gottlieb method, but with pure reagents this is an insignificant issue in analysis of cow milk (Hooi et al., 2004). There is also concern with milks assayed by the Röse-Gottlieb method that changes in pan weight due to aluminum oxidation can increase $\mathrm{RSD}_{\mathrm{r}}$ and that ruminant milk fats may be difficult to solubilize at the time of final ether addition unless the fat is hot. The latter is unlikely to be an issue with polyunsaturated marine mammal milk lipids that are liquid at room temperature, but this has not been studied. In our laboratory, the $\mathrm{RSD}_{\mathrm{r}}$ for fat in Weddell seal milk was somewhat higher $(0.96 \% \pm$ $0.09)$ than when fresh cow milk is analyzed $(0.2-0.4 \%$; Barbano et al., 1988; Lynch et al., 2003). Milks that have been frozen and thawed may be somewhat destabilized due to presumed MFG disruption, making representative subsampling more difficult. The RöseGottlieb/Mojonnier method is the method of choice for marine mammal milks except where extensive lipolysis has occurred, as in gastric milk (Iverson et al., 1992) or in chemically preserved, nonfrozen milk (Ochoa-Acuna et al., 1999) that contains a large proportion of FFA. Free fatty acids react with ammonium hydroxide to form soaps that are incompletely extracted, leading to systematic error. The magnitude of error is dependent on the degree of lipolysis (Iverson, 1988; Iverson and Oftedal, 1995). Minor lipolysis may occur in marine mammal milks that have been stored frozen for many years (e.g., $0.2 \%$ FFA in sea lion milk; Iverson et al., 1992), but whether this small fatty acid amount has any effect on fat extraction is unknown.

Another fat extraction procedure commonly used with marine products is the Folch method, which involves lipid extraction with chloroform and methanol, and permits extraction of lipid classes for subsequent fatty acid analysis (Budge et al., 2006). In human milk that contained up to $8 \%$ fat, a modified Folch method (solvent:sample ratio 9:1) produced results that were tightly correlated (linear regression $r^{2}=0.994$ ) to the Röse-Gottlieb, with a small intercept (0.068) and a proportional error (slope) of 0.967 (Hundrieser et al., 1984). However, method performance may be different for high-fat marine mammal milks. Even after increase in solvent:sample ratio to 50:1 to improve lipid re- covery, the Folch method underestimated fat content of gray seal (Halichoerus grypus) milk by about $10 \%$ compared with the Röse-Gottlieb method (Iverson et al., 2010). We re-evaluated the graphed data ( $\mathrm{n}=$ 71) in accordance with our criteria: the Pearson $r$ was significant but quite low (0.918); Passing-Bablok rank regression yielded a slope (0.923) and intercept $(-0.23)$ not significantly different from 1 and 0 , respectively; the Wilcoxon signed rank test (for non-normal data) indicated a significant difference $(P<0.001)$ between methods, and the predictive performance was low (PRESS $\left.r^{2}=0.37\right)$. Thus, the Folch method not only underestimates fat content in high-fat milks, but the degree of underestimation is poorly predicted.

In a study of Weddell seal milk, Wheatley et al. (2008) obtained similar results for milk fat by a Folch procedure $(48.7 \%)$ and a simpler chloroform-methanol method $(48.1 \%, \mathrm{n}=8)$ developed for lipid extraction of lean fish tissue (Bligh and Dyer, 1959). However in a comparison of Bligh and Dyer versus Folch methods for analysis of fat content of fish, Iverson et al. (2001) demonstrated good correspondence for samples with low fat content but large discrepancies for high-fat samples. Whether this is true for milk as well is not known, but it appears likely that both the Folch and the Bligh and Dyer methods underestimate the fat content of high fat-milks. As noted above, the Bligh and Dyer method was the procedure used by Arnould et al. (1995) for evaluation of fat predictions by the stoichiometric approach, and the discrepancy between methods may have been greater if a more accurate method of fat extraction had been employed.

It is not known if acid hydrolysis with volumetric fat measurement (Babcock and Gerber methods: Herreid, 1942; Ling, 1957; Hooi et al., 2004) produces comparable results for marine mammal milks (e.g., Bryden, 1968; Baker, 1990; West et al., 2007) as the Röse-Gottlieb/ Mojonnier method, although with minor alterations to sample delivery and measurement temperature, method correspondence is good for cow milk (Barbano et al., 1988; Kleyn et al., 2001; Lynch et al., 2003). However, it should be emphasized that marine mammal milk lipids have very different fatty acid patterns (Iverson and Oftedal, 1995) - and thus different expected specific gravity (Sales-Cruz et al., 2010) - than cow milk lipids, which suggests correction factors may be required for accurate Babcock or Gerber fat measurements. A simplified method of measuring the cream layer in hematocrit tubes following centrifugation of milk has been used in some mammals (Oftedal and Iverson, 1995) but not, to our knowledge, in marine mammals. This method requires extensive calibration against accurate fat extraction data for the same samples. Linzell and Fleet (1969) reported that species-specific factors for 
converting cream volume to fat mass ranged from 0.58 to 0.79 , presumably because numerous factors affect the packing of milk fat globules, but these have not been studied for marine mammal milks.

We also evaluated the sugar prediction generated by the carbon stoichiometric procedure. On an OM basis, sugar comprised $1.6 \% \pm 0.08$ by the phenol-sulfuric acid method ( $\mathrm{n}=47)$, but the stoichiometric predictions were negative in more than half of the samples, and averaged $-0.30 \pm 0.44 \%(\mathrm{n}=47)$, which was not significantly different from zero. Arnould et al. (1995) also found that the stoichiometric approach did not yield reliable sugar results in Antarctic fur seals, but this was not surprising as otariid milks contain such small amounts of sugar (Oftedal, 2011). Whether carbon stoichiometry could be used with more success to assess sugar in high-sugar, low-fat milks cannot be assessed by our data. Further research is also needed on the phenol-sulfuric acid method, as it depends on color development due to formation of furan derivatives (Robyt, 1998; Brummer and Cui, 2005), but $N$-acetylated sugars such as $\mathrm{N}$-acetyl glucosamine, $\mathrm{N}$-acetyl galactosamine, and $N$-acetyl neuraminic acid (Neu5Ac, sialic acid) do not produce furan derivatives and thus do not react with phenol (Masuko et al., 2005). Given that such monosaccharide moieties are found as constituents of the oligosaccharides present in many marine mammal milks (Urashima et al., 2002, 2003a,b, 2004, 2011; Uemura et al., 2005; Oftedal, 2011), it is likely that the phenol-sulfuric acid method underestimates total sugar in these taxa, but the degree of underestimation is not known. The colorimetric responses to glucose and galactose also differ somewhat; the results presented herein are equivalent to that of an equimolar mixture of glucose and galactose, due to use of lactose monohydrate as the standard. The $\mathrm{RSD}_{\mathrm{r}}$ was also higher $(5.9 \%)$ than appropriate for a reference method, reflecting both an inherent variability in this assay and the low absolute sugar content $(0.92 \pm 0.031 \%$ of WM, n $=47$ ) in whole Weddell seal milk. In our laboratory, the phenol-sulfuric acid method has an $\mathrm{RSD}_{\mathrm{r}}$ of $2.17 \pm$ $0.25 \%$ for store-bought homogenized cow milk, which is both considerably more homogeneous and has a higher sugar content $(4.88 \% \pm 0.052, \mathrm{n}=24)$ than marine mammal milks. On the other hand, analytical methods that depend on physical or chemical properties of lactose, such as polarimetric, reducing sugar, and enzymatic methods, may underestimate total sugar content to a much greater degree than the phenol-sulfuric acid method (Oftedal and Iverson, 1995; Eisert et al., 2013). For example, by the phenol-sulfuric acid method, we measured an average total sugar content of $0.84 \% \pm$ $0.03 \%$ of WM in Weddell seal milk (Eisert et al., 2013), whereas the amount of lactose by an enzymatic analysis was only $0.028 \% \pm 0.003 \%$ of $\mathrm{WM}, \mathrm{n}=16$ (G. K. Barrell, unpublished data). Nonetheless, the high $\mathrm{RSD}_{\mathrm{r}}$ and failure to measure $\mathrm{N}$-acetylated sugars indicate that the phenol-sulfuric acid method is of limited value as a reference method for total sugar in milk, but we continue to use it until a better alternative can be established.

\section{Prediction of GE of Milk}

The energy content of mammalian milks is often calculated from proximate constituents with the aim of estimating energy transfer rates from mother to pup during lactation (Oftedal, 1984). We predicted milk energy content using factors derived by Perrin (1958) from cow, sheep, goat, pig, and human milk, and applied generally to mammalian milks (Oftedal, 1984). Predicted and measured energy matched very well (Figure 1): the Pearson $r$ was high, the regression slope and intercept were not different from 1 and 0 , there was no significant difference in paired values, and the PRESS $r^{2}(0.963)$ was high, indicating good predictive performance (Table 1). Thus the factors used (38.1, 24.5 , and $16.5 \mathrm{~kJ} / \mathrm{g}$ for the energy content of $\mathrm{CP}$, fat, and sugar) appeared to be correct.

This tight fit to the Perrin factors was somewhat surprising. Oftedal et al. (1993) reported that these factors underestimated the measured energy content of hooded seal milk (predicted $35.0 \mathrm{~kJ} / \mathrm{g}$, measured $37.0 \mathrm{~kJ} / \mathrm{g}$; paired $t$-test, $P<0.0001, \mathrm{n}=15$ ). Fat extracted by the Röse-Gottlieb method from hooded seal milk was found to contain $39.3 \mathrm{~kJ} / \mathrm{g}$ and this factor was recommended for pinniped milks. However, the revised prediction still somewhat underestimated energy content $(36.0 \mathrm{~kJ} / \mathrm{g}$; Oftedal et al., 1993) and predictive performance was not evaluated. As a check, we also measured energy content of pooled extracted fat from Weddell seal milk and obtained a value $(38.2 \mathrm{~kJ} / \mathrm{g})$ very close to the Perrin factor $(38.1 \mathrm{~kJ} / \mathrm{g})$. It is likely that the GE content $(\mathrm{kJ} / \mathrm{g})$ of fat varies in accord with FA composition, as different FA have different heats of combustion (Blaxter, 1989). If so, species-specific energy factors for milk fat may be appropriate, given that fat contributes so much of the energy in marine mammal milks (Oftedal, 2011). Further research is needed to encompass a broader range of mammalian milks.

\section{CONCLUSIONS}

Choice of analytical method can determine outcome and interpretation of milk analyses. Although standard methods of milk analysis tend to be laborious and time consuming, they are more likely to provide accurate results for milks of different species, as long as the analytical response is relatively independent of 
specific constituents. Validation studies in which only a narrow sample range is included or the comparison is restricted to a general description of correlation may lead to inappropriate acceptance of alternative analytical methods. Although we conclude that the modified Dumas (CHN) method yields valid data (i.e., equivalent to macro-Kjeldahl N) for high-fat seal milk, many of the alternative methods used for milk protein in marine mammals and other species suffer from poor repeatability, constant and proportional error, and poor predictive performance. Alternative protein methods may over- or underestimate milk protein, whereas alternative fat and sugar methods typically underestimate these constituents, which may lead to erroneous conclusions about the proportions of constituents and predicted energy content of marine mammal milks. Marine mammalogists have to overcome great logistic difficulties in obtaining milk samples, whether in the field or in a captive facility. It seems wasteful, and potentially misleading, to consume milk samples in analytical procedures that do not produce reliable results. We hope that wider adoption of standard methods and more rigorous assessment of alternative methods will improve our ability to understand milk composition of these remarkable animals.

\section{ACKNOWLEDGMENTS}

Field research on Weddell seal lactation was supported by Antarctica New Zealand (field logistics in 1998), New Zealand Lotteries Science Grants Board, a Science Research Grant no. AP52833 to G. K. Barrell, a Smithsonian Visiting Scholar grant to R. Eisert, and a National Science Foundation-Office of Polar Programs grant ANT-0538592 to O. T. Oftedal, R. Eisert, and D. Boness. We thank our teams who assisted in the field in 1998 (J. Banks, D. Geddes, P. Isherwood, S. Leslie, B. Stewart, and H. Stoklosinski from Lincoln University, Lincoln New Zealand, and particularly S. Ramdohr from the Alfred-Wegener-Institute of Bremerhaven, Germany) and in 2006 (D. Boness, D. Boritt, R. Joss, B. Krafft, M. Lara, M. Riser, J. Robinson, and H. Routti from the Smithsonian Institution, Washington, DC). We also thank the staff at Scott Base and McMurdo Station for their support of our field efforts. We are grateful to laboratory manager M. Jakubasz for logistic and laboratory support at the Nutrition Laboratory of the Smithsonian National Zoological Park, and the interns and technicians who assisted with various aspects of milk analysis: J. Behler, D. Boen, S. Childs, M. Collins, R. Harley, D. Hellinga, K. Messerschmidt, L. Nelson, C. Petzinger, K. Roback, K. Smythe, M. Snyder, and S. Wong. We thank W. Hood, Auburn University (Auburn, AL) for her ideas about how best to estimate input factors for the stoichiometric procedure.

\section{REFERENCES}

Albanell, E., G. Caja, X. Such, M. Rovai, A. Salama, and R. Casals. 2003. Determination of fat, protein, casein, total solids, and somatic cell count in goat's milk by near-infrared reflectance spectroscopy. J. AOAC Int. 86:746-752.

Allen, D. 1974. The relationship between variable selection and data augmentation and a method for prediction. Technometrics $16: 125-127$.

AOAC International. 1995. Method 989.05 in Official Methods of Analysis. AOAC International, Arlington, VA.

Arnould, J. P. Y., and I. L. Boyd. 1995. Inter- and intra-annual variation in milk composition in Antarctic fur seals (Arctocephalus gazella). Physiol. Zool. 68:1164-1180.

Arnould, J. P. Y., I. L. Boyd, and A. Clarke. 1995. A simplified method for determining the gross chemical composition of pinniped milk samples. Can. J. Zool. 73:404-410.

Arnould, J. P. Y., and M. A. Hindell. 1999. The composition of Australian fur seal (Arctocephalus pusillus doriferus) milk throughout lactation. Physiol. Biochem. Zool. 72:605-612.

Atwood, C. S., and P. E. Hartmann. 1992. Collection of fore and hind milk from the sow and the changes in milk composition during suckling. J. Dairy Res. 59:287-298.

Baker, J. R. 1990. Grey seal (Halichoerus grypus) milk composition and its variation over lactation. Br. Vet. J. 146:233-238.

Barbano, D. M., and J. L. Clark. 1989. Infrared milk analysis-Challenges for the future. J. Dairy Sci. 72:1627-1636.

Barbano, D. M., J. Clark, and C. Dunham. 1988. Comparison of Babcock and ether extraction methods for determination of fat content of milk: Collaborative study. J. Assoc. Off. Anal. Chem. 71:898-914.

Barbano, D. M., J. Clark, C. Dunham, and J. Fleming. 1990. Kjeldahl method for determination of total nitrogen content of milk: Collaborative study. J. Assoc. Off. Anal. Chem. 73:849-859.

Barbano, D. M., and J. M. Lynch. 2006. Major advances in testing of dairy products: Milk component and dairy product attribute testing. J. Dairy Sci. 89:1189-1194.

Barbano, D. M., J. Lynch, and J. R. Fleming. 1991. Direct and indirect determination of true protein content of milk by Kjeldahl analysis: Collaborative study. J. Assoc. Off. Anal. Chem. 74:281-288.

Blaxter, K. L. 1989. Energy Metabolism in Animals and Man. Cambridge University Press, Cambridge, UK.

Bligh, E. G., and W. Dyer. 1959. A rapid method of total lipid extraction and purification. Can. J. Biochem. Physiol. 37:911-917.

Bradford, M. M. 1976. A rapid and sensitive method for the quantitation of microgram quantities of protein utilizing the principle of protein dye-binding. Anal. Biochem. 72:248-254.

Bradstreet, R. 1965. The Kjeldahl Method for Organic Nitrogen. Academic Press, New York, NY.

Brummer, Y., and S. W. Cui. 2005. Understanding carbohydrate analysis. Pages 67-104 in Food Carbohydrates: Chemistry, Physical Properties, and Applications. S. Cui, ed. CRC Press, Boca Raton, FL.

Bryden, M. M. 1968. Lactation and suckling in relation to early growth of the southern elephant seal, Mirounga leonina. Aust. J. Zool. 16:739-747.

Budge, S. M., S. J. Iverson, and H. N. Koopman. 2006. Studying the trophic ecology in marine ecosystems using fatty acids: A primer on analysis and interpretation. Mar. Mamm. Sci. 22:759-801.

Carlini, A. R., M. E. I. Marquez, G. Soave, D. F. Vergani, and P. A. R. Ferrer. 1994. Southern elephant seal, Mirounga leonina: Composition of milk during lactation. Polar Biol. 14:37-42.

Case, R., R. Bradley, and R. Williams. 1985. Chemical and physical methods. Pages 327-404 in Standard Methods for the Examination of Dairy Products. 15th ed. G. Richardson, ed. American Public Health Association, Washington, DC. 
Clark, J. L., D. M. Barbano, and C. E. Dunham. 1989. Comparison of two methods for determination of total solids content of milk: Collaborative study. J. Assoc. Off. Anal. Chem. 72:712-718.

Colenbrander, V. F., and T. G. Martin. 1971. Orange G dye binding for determination of protein of sow's milk. J. Dairy Sci. 54:531533.

Cooper, A. P. 1840. On the Anatomy of the Breast. Longmans, London, UK.

Dielman, T. 2005. Applied Regression Analysis: A Second Course in Business and Economic Statistics. Brooks/Cole Thomson Learning, Belmont, CA.

Eisert, R. 2011. Hypercarnivory and the brain: Protein requirements of cats reconsidered. J. Comp. Physiol. B 181:1-17.

Eisert, R., O. T. Oftedal, and G. K. Barrell. 2013. Milk composition in the Weddell seal (Leptonychotes weddellii): Evidence for a functional role of milk sugar in pinnipeds. Physiol. Biochem. Zool. $86: 159-175$.

Etheridge, R. D., G. M. Pesti, and E. H. Foster. 1998. A comparison of nitrogen values obtained utilizing the Kjeldahl nitrogen and Dumas combustion methodologies (Leco CNS 2000) on samples typical of an animal nutrition analytical laboratory. Anim. Feed Sci. Technol. 73:21-28.

Ferguson, S. H. 2006. The influences of environment, mating habitat, and predation on evolution of pinniped lactation strategies. J. Mamm. Evol. 13:63-82.

Fox, P. 2003. Milk proteins: General and historical aspects. Pages 1-48 in Advanced Dairy Chemistry: I. Proteins (A). P. Fox and P. McSweeney, ed. Kluwer Academic, New York, NY.

Frankland, P., and F. Hambly. 1890. The composition of the milk of the bottle-nose whale (Globicephalus melas). Chem News J Phys Sci 61:63.

Gamel, C. M., R. W. Davis, J. H. M. David, M. A. Meyer, and E. Brandon. 2005. Reproductive energetics and female attendance patterns of Cape fur seals (Arctocephalus pusillus pusillus) during early lactation. Am. Midl. Nat. 153:152-170.

Gnaiger, E., and G. Bitterlich. 1984. Proximate biochemical composition and caloric content calculated from elemental CHN analysis: A stoichiometric concept. Oecologia 62:289-298.

Hedberg, G. E., A. E. Derocher, M. Andersen, Q. Rogers, E. DePeters, B. Lönnerdal, L. Mazzaro, R. Chesney, and B. Hollis. 2011. Milk composition in free-ranging polar bears (Ursus maritimus) as a model for captive rearing milk formula. Zoo Biol. 30:550-565.

Herreid, E. O. 1942. The Babcock test: A review of the literature. J. Dairy Sci. 25:335-370.

Holsinger, V. 1988. Lactose. Pages 279-342 in Fundamentals of Dairy Chemistry. 3rd ed. N. Wong, R. Jenness, M. Keeney, and E. Marth, ed. Van Nostrand Reinhold Co., New York, NY.

Hood, W., M. Voltura, and O. T. Oftedal. 2009. Methods of measuring milk composition and yield in small mammals. Pages 529-553 in Ecological and Behavioral Methods for the Study of Bats. T. Kunz and S. Parsons, ed. Johns Hopkins University Press, Baltimore, MD.

Hooi, R., D. M. Barbano, R. Bradley, D. Budde, M. Bulthaus, M. Chettiar, J. Lynch, and R. Reddy. 2004. Chemical and physical methods. Pages 363-536 in Standard Methods for the Examination of Dairy Products. 17th ed. H. Wehr and J. Frank, ed. American Public Health Association, Washington, DC.

Hundrieser, K., R. Clark, R. Jensen, and A. Ferris. 1984. A comparison of methods for determination of total lipids in human milk. Nutr. Res. 4:21-26.

Isengard, H.-D., R. Kling, and C. Reh. 2006. Proposal of a new reference method to determine the water content of dried dairy products. Food Chem. 96:418-422.

ISO-IDF. 2002. Milk and milk products-Determination of nitrogen content-Routine method using combustion according to the Dumas principle. International standard ISO 14891, IDF 185. International Organization for Standardization (ISO), Geneva, Switzerland; International Dairy Federation (IDF), Brussels, Belgium.

Iverson, S. J. 1988. Composition, Intake and Gastric Digestion of Milk Lipids in Pinnipeds. PhD Diss. University of Maryland, College Park.
Iverson, S. J., S. L. C. Lang, and M. H. Cooper. 2001. Comparison of the Bligh and Dyer and Folch methods for total lipid determination in a broad range of marine tissue. Lipids 36:1283-1287.

Iverson, S. J., and O. T. Oftedal. 1995. Comparative analysis of nonhuman milks. B. Phylogenetic and ecological variation in the fatty acid composition of milks. Pages 789-827 in Handbook of Milk Composition. R. Jensen, ed. Academic Press, San Diego, CA.

Iverson, S. J., J. Sampugna, and O. T. Oftedal. 1992. Positional specificity of gastric hydrolysis of long-chain n-3 polyunsaturated fatty acids of seal milk triglycerides. Lipids 27:870-878.

Iverson, S. J., C. E. Sparling, T. M. Williams, S. L. C. Lang, and W. D. Bowen. 2010. Measurement of individual and population energetics of marine mammals. Pages 165-190 in Marine Mammal Ecology and Conservation. A Handbook of Techniques. I. L. Boyd and W. D. Bowen, ed. Oxford University Press, Oxford, UK.

Kamizake, N. K. K., M. M. Gonçalves, C. T. B. V. Zaia, and D. A. Zaia. 2003. Determination of total proteins in cow milk powder samples: A comparative study between the Kjeldahl method and spectrophotometric methods. J. Food Compos. Anal. 16:507-516.

Keller, R. P. and M. C. Neville. 1986. Determination of total protein in human milk: Comparison of methods. Clin. Chem. 32:120-123.

Kleyn, D. H., J. Lynch, D. Barbano, M. Bloom, and M. Mitchell. 2001. Determination of fat in raw and processed milks by the Gerber method: Collaborative study. J. AOAC Int. 84:1499-1508.

Koch, F., and T. McMeekin. 1924. A new direct Nesslerization microKjeldahl method and modification of Nessler-Folin reagent for ammonia. J. Am. Chem. Soc. 46:2066-2069.

Kretzmann, M. B., D. P. Costa, and B. J. LeBoeuf. 1993. Maternal energy investment in elephant seal pups: Evidence for sexual equality? Am. Nat. 141:466-480.

Lang, S. L., S. J. Iverson, and W. D. Bowen. 2009. Repeatability in lactation performance and the consequences for maternal reproductive success in gray seals. Ecology 90:2513-2523.

Ling, E. 1957. A Textbook of Dairy Chemistry. Vol. 2. Practical. 3rd rev. ed. Philosophical Library, New York, NY.

Linnet, K. 1993. Evaluation of regression procedures for method comparison studies. Clin. Chem. 39:424-432.

Linnet, K. 1998. Performance of Deming regression analysis in case of misspecified analytical error ratio in method comparison studies. Clin. Chem. 44:1024-1031.

Linnet, K. 1999. Necessary sample size for method comparison studies based on regression analysis. Clin. Chem. 45:882-894.

Linzell, J. L., and I. R. Fleet. 1969. Accuracy of the micromethod of estimating milk fat concentration by high-speed centrifugation in capillary tubes. J. Dairy Sci. 52:1685-1687.

Lynch, J. M., and D. M. Barbano. 1999. Kjeldahl nitrogen analysis as a reference method for protein determination in dairy products. J. AOAC Int. 82:1389-1398.

Lynch, J. M., D. Barbano, P. Healy, and J. Fleming. 2003. Effectiveness of temperature modification in decreasing the bias in milk fat test results between the Babcock and ether extraction methods. J. AOAC Int. 86:768-774

Marier, J., and M. Boulet. 1959. Direct analysis of lactose in milk and serum. J. Dairy Sci. 42:1390-1391.

Masuko, T., A. Minami, N. Iwasaki, T. Majima, S.-I. Nishimura, and Y. C. Lee. 2005. Carbohydrate analysis by a phenol-sulfuric acid method in microplate format. Anal. Biochem. 339:69-72.

Mather, I. H. 2011. Milk fat globule membrane. Pages 680-690 in Encyclopedia of Dairy Sciences. 3rd ed. J. Fuquay, P. Fox, and P. McSweeney, ed. Academic Press, San Diego, CA.

McDonald, B. I., and D. E. Crocker. 2006. Physiology and behavior influence lactation efficiency in northern elephant seals (Mirounga angustirostris). Physiol. Biochem. Zool. 79:484-496.

Mellish, J. A., S. J. Iverson, and W. D. Bowen. 2000. Metabolic compensation during high energy output in fasting, lactating grey seals (Halichoerus grypus): Metabolic ceilings revisited. Proc. Biol. Sci. 267:1245-1251.

Myburgh, J., G. Osthoff, A. Hugo, M. De Wit, K. Nel, and D. Fourie 2012. Comparison of the milk composition of free-ranging indigenous African cattle breeds. S. Afr. J. Anim. Sci. 42:1-14. 
Ochoa-Acuna, H., J. M. Francis, and O. T. Oftedal. 1999. Influence of long intersuckling interval on composition of milk in the Juan Fernandez fur seal, Arctocephalus philippii. J. Mammal. 80:758-767.

Oftedal, O. T. 1984. Milk composition, milk yield and energy output at peak lactation: A comparative review. Symp Zool Soc London 51:33-85.

Oftedal, O. T. 1993. The adaptation of milk secretion to the constraints of fasting in bears, seals, and baleen whales. J. Dairy Sci. $76: 3234-3246$

Oftedal, O. T. 1997. Lactation in whales and dolphins: Evidence of divergence between baleen- and toothed-species. J. Mammary Gland Biol. Neoplasia 2:205-230.

Oftedal, O. T. 2011. Milk of marine mammals. Pages 563-580 in Encyclopedia of Dairy Sciences. Vol. 3. 2nd ed. J. Fuquay, P. Fox, and P. McSweeney, ed. Academic Press, San Diego, CA.

Oftedal, O. T., D. J. Boness, and W. D. Bowen. 1988. The composition of hooded seal (Cystophora cristata) milk: An adaptation for postnatal fattening. Can. J. Zool. 66:318-322.

Oftedal, O. T., D. J. Boness, and R. Tedman. 1987. The behavior, physiology and anatomy of lactation in the Pinnipedia. Pages 175-245 in Current Mammalogy. Vol. 1. H. Genoways, ed. Plenum Press, New York, NY.

Oftedal, O. T., W. D. Bowen, and D. J. Boness. 1993. Energy transfer by lactating hooded seals and nutrient deposition in their pups during the 4 days from birth to weaning. Physiol. Zool. 66:412436.

Oftedal, O. T., and S. J. Iverson. 1987. Hydrogen isotope methodology for the measurement of milk intake and energetics of growth in suckling young. Pages 67-96 in Approaches to Marine Mammal Energetics. A. D. Huntley, D. P. Costa, G. A. J. Worthy, and M. A. Castellini, ed. Allen Press, Lawrence, KS.

Oftedal, O. T., and S. J. Iverson. 1995. Comparative analysis of nonhuman milks. A. Phylogenetic variation in the gross composition of milks. Pages 749-789 in Handbook of Milk Composition. R. Jensen, ed. Academic Press, New York, NY.

Passing, H., and W. Bablok. 1983. A new biometrical procedure for testing the equality of measurements from two different analytical methods. Application of linear regression procedures for method comparison studies in clinical chemistry, Part I. J. Clin. Chem. Clin. Biochem. 21:709-720.

Peeler, J. T., W. Horwitz, and R. Albert. 1989. Precision parameters of standard methods of analysis for dairy products. J. Assoc. Off. Anal. Chem. 72:784-806.

Perrin, D. 1958. The calorific value of milk of different species. J. Dairy Res. 25:215-220.

Pervaiz, S., and K. Brew. 1986. Composition of the milks of the bottlenose dolphin (Tursiops trucatus) and the Florida manatee (Trichechus manatus latirostris). Comp. Biochem. Physiol. A 84:357360 .

Purdie, P. 1885. Chemical composition of the milk of the porpoise. Chem. News. J. Phys. Sci. 52:70.

Reh, C., S. Bhat, and S. Berrut. 2004. Determination of water content in powdered milk. Food Chem. 86:457-464.

Reich, C. M., and J. P. Y. Arnould. 2007. Evolution of Pinnipedia lactation strategies: A potential role for $\alpha$-lactalbumin? Biol. Lett. 3:546-549.

Riet-Sapriza, F. G., P. J. Duignan, B. L. Chilvers, I. S. Wilkinson, N. Lopez-Villalobos, D. D. S. MacKenzie, A. MacGibbon, D. P. Costa, and N. Gales. 2012. Interannual and individual variation in milk composition of New Zealand sea lions (Phocarctos hookeri). J. Mammal. 93:1006-1016.

Riet-Sapriza, F. G., N. Lopez-Villalobos, D. D. S. MacKenzie, P. J. Duignan, A. MacGibbon, B. L. Chilvers, and I. S. Wilkinson. 2009. Comparison of methods for the analysis of New Zealand sea lion, Phocarctos hookeri, milk. N. Z. J. Mar. Freshw. Res. 43:997-1006.

Robyt, J. 1998. Essentials of Carbohydrate Chemistry. Springer-Verlag, New York, NY.

Rückold, S., K. Grobecker, and H.-D. Isengard. 2001. Water as a source of errors in reference materials. Fresenius J. Anal. Chem. 370:189-193.
Sales-Cruz, M., G. Aca-Aca, O. Sanchez-Daza, and T. Lopez-Arenas. 2010. Predicting critical properties, density and viscosity of fatty acids, triacylglycerols and methyl esters by group contribution methods. Pages 1762-1768 in 20th Eur. Symp. Computer Aided Process Engineering. S. Pierucci, G. Buzzi Ferraris, eds. Elsevier BV, New York, NY.

Sapan, C. V., R. L. Lundblad, and N. C. Price. 1999. Colorimetric protein assay techniques. Biotechnol. Appl. Biochem. 29:99-108.

Schulz, T. M., and W. D. Bowen. 2004. Pinniped lactation strategies: Evaluation of data on maternal and offspring life history traits. Mar. Mamm. Sci. 20:86-114.

Schulz, T. M., and W. D. Bowen. 2005. The evolution of lactation strategies in pinnipeds: A phylogenetic analysis. Ecol. Monogr. $75: 159-177$.

Seligmann, E., and J. Farber. 1971. Freeze drying and residual moisture. Cryobiology 8:138-144.

Sharp, J. A., C. Lefevre, and K. R. Nicholas. 2008. Lack of functional alpha-lactalbumin prevents involution in Cape fur seals and identifies the protein as an apoptotic milk factor in mammary gland involution. BMC Biol. 6:48 http://dx.doi.org/10.1186/1741-7007$6-48$.

Sheiner, L. B., and S. L. Beal. 1981. Some suggestions for measuring predictive performance. J. Pharmacokinet. Biopharm. 9:503-512.

Sherbon, J. W., J. B. Mickle, and W. D. Ward. 1978. Total solids in nonfat dry milk by atmospheric drying in a forced air oven. J. Assoc. Off. Anal. Chem. 61:550-557.

Simonne, A., E. Simonne, R. Eitenmiller, H. Mills, and C. Cresman. 1997. Could the Dumas method replace the Kjeldahl digestion for nitrogen and crude protein determinations in foods? J. Sci. Food Agric. 73:39-45.

Stöckl, D., K. DeWitte, and L. M. Thienpont. 1998. Validity of linear regression in method comparison studies: Is it limited by the statistical model or the quality of the input data? Clin. Chem. 44:2340-2346.

Tedman, R. A. 1983. Ultrastructural morphology of the mammary gland with observations on the size distribution of fat droplets in milk of the Weddell seal Leptonychotes weddelli (Pinnipedia). J. Zool. 200:131-141.

Thompson, M., L. Owen, K. Wilkinson, R. Wood, and A. Damant. 2002. A comparison of the Kjeldahl and Dumas methods for the determination of protein in foods, using data from a proficiency testing scheme. Analyst 127:1666-1668.

Tremblay, L., M. Laporte, J. Leonil, D. Dupont, and P. Paquin. 2003. Quantitation of proteins in milk and milk products. Pages 49-138 in Advanced Dairy Chemistry. Vol. 1. Proteins, Part A. 3rd ed. P. Fox and P. McSweeney, ed. Kluwer Academic/Plenum Publishers, New York, NY.

Uemura, Y., S. Asakuma, T. Nakamura, I. Arai, M. Taki, and T. Urashima. 2005. Occurrence of a unique sialyl tetrasaccharide in colostrum of a bottlenose dolphin (Tursiops truncatus). Biochim. Biophys. Acta 1725:290-297.

Urashima, T., M. Arita, M. Yoshida, T. Nakamura, I. Arai, T. Saito, J. P. Arnould, K. M. Kovacs, and C. Lydersen. 2001. Chemical characterisation of the oligosaccharides in hooded seal (Cystophora cristata) and Australian fur seal (Arctocephalus pusillus doriferus) milk. Comp. Biochem. Physiol. B Biochem. Mol. Biol. 128:307323.

Urashima, T., S. Asakuma, M. Kitaoka, and M. Messer. 2011. Lactose and oligosaccharides: Indigenous oligosaccharides in milk. Pages 241-273 in Encyclopedia of Dairy Sciences. Vol. 3. 2nd ed. J. W. Fuquay, P. F. Fox, and P. L. H. McSweeney, ed. Academic Press, San Diego, CA.

Urashima, T., H. Nagata, T. Nakamura, I. Arai, T. Saito, K. Imazu, T. Hayashi, A. E. Derocher, and Ø. Wiig. 2003a. Differences in oligosaccharide pattern of a sample of polar bear colostrum and mid-lactation milk. Comp. Biochem. Physiol. B Biochem. Mol. Biol. 136:887-896.

Urashima, T., T. Nakamura, D. Nakagawa, M. Noda, I. Arai, T. Saito, C. Lydersen, and K. M. Kovacs. 2004. Characterization of oligosaccharides in milk of bearded seal (Erignathus barbatus). Comp. Biochem. Physiol. B Biochem. Mol. Biol. 138:1-18. 
Urashima, T., T. Nakamura, K. Yamaguchi, J. Munakata, I. Arai, T. Saito, C. Lydersen, and K. M. Kovacs. 2003b. Chemical characterization of the oligosaccharides in milk of high Arctic harbour seal (Phoca vitulina vitulina). Comp. Biochem. Physiol. A Mol. Integr. Physiol. 135:549-563.

Urashima, T., H. Sato, J. Munakata, T. Nakamura, I. Arai, T. Saito, M. Tetsuka, Y. Fukui, H. Ishikawa, C. Lydersen, and K. M. Kovacs. 2002. Chemical characterization of the oligosaccharides in beluga (Delphinapterus leucas) and Minke whale (Balaenoptera acutorostrata) milk. Comp. Biochem. Physiol. B Biochem. Mol. Biol. 132:611-624.

van Boekel, M. A. J. S. 1998. Effects of heating on Maillard reactions in milk. Food Chem. 62:403-414

Verheul, F. E., M. J. van de Bosch, P. J. Cornelissen, and J. J. Waelkens. 1986. Simplified and rapid methods for the determination of protein, fat and lactose in human milk and the energy intake by the breast-fed infant. J. Clin. Chem. Clin. Biochem. 24:341-346.

Wehr, H. 2004. Standard methods. Pages 1-20 in Standard Methods for the Examination of Dairy Products. 17th ed. H. Wehr and J. Frank, ed. American Public Health Association, Washington, DC.

West, K. L., O. T. Oftedal, J. R. Carpenter, B. J. Krames, M. Campbell, and J. C. Sweeney. 2007. Effect of lactation stage and concurrent pregnancy on milk composition in the bottlenose dolphin. J. Zool. (Lond.) 273:148-160.

Wheatley, K. E., C. J. A. Bradshaw, R. G. Harcourt, and M. A. Hindell. 2008. Feast or famine: Evidence for mixed capital-income breeding strategies in Weddell seals. Oecologia 155:11-20.

Wiles, P. G., I. Gray, and R. Kissling. 1998. Routine analysis of proteins by Kjeldahl and Dumas methods: Review and interlaboratory study using dairy products. J. AOAC Int. 81:620-632. 